\title{
Extreme Floods in the Eastern Part of Europe: Large-Scale Drivers and Associated Impacts
}

\author{
Monica Ionita ${ }^{1}$ (D) and Viorica Nagavciuc $1,2, *$ (D) \\ 1 Alfred Wegener Institute Helmholtz Center for Polar and Marine Research, 27570 Bremerhaven, Germany; \\ Monica.Ionita@awi.de \\ 2 Forest Biometrics Laboratory, Faculty of Forestry, Stefan Cel Mare University, 720229 Suceava, Romania \\ * Correspondence: viorica.nagavciuc@awi.de; Tel.: +49-(471)-4831-1845
}

Citation: Ionita, M.; Nagavciuc, V. Extreme Floods in the Eastern Part of Europe: Large-Scale Drivers and Associated Impacts. Water 2021, 13, 1122. https://doi.org/10.3390/ w13081122

Academic Editor: Athanasios Loukas

Received: 17 March 2021

Accepted: 16 April 2021

Published: 19 April 2021

Publisher's Note: MDPI stays neutral with regard to jurisdictional claims in published maps and institutional affiliations.

Copyright: (c) 2021 by the authors. Licensee MDPI, Basel, Switzerland. This article is an open access article distributed under the terms and conditions of the Creative Commons Attribution (CC BY) license (https:// creativecommons.org/licenses/by/ $4.0 /)$.

\begin{abstract}
The role of the large-scale atmospheric circulation in producing heavy rainfall events and floods in the eastern part of Europe, with a special focus on the Siret and Prut catchment areas (Romania), is analyzed in this study. Moreover, a detailed analysis of the socio-economic impacts of the most extreme flood events (e.g., July 2008, June-July 2010, and June 2020) is given. Analysis of the largest flood events indicates that the flood peaks have been preceded up to 6 days in advance by intrusions of high Potential Vorticity (PV) anomalies toward the southeastern part of Europe, persistent cut-off lows over the analyzed region, and increased water vapor transport over the catchment areas of Siret and Prut Rivers. The vertically integrated water vapor transport prior to the flood peak exceeds $300 \mathrm{~kg} \mathrm{~m}^{-1} \mathrm{~s}^{-1}$, leading to heavy rainfall events. We also show that the implementation of the Flood Management Plan in Romania had positive results during the 2020 flood event compared with the other flood events, when the authorities took several precaution measurements that mitigated in a better way the socio-economic impact and risks of the flood event. The results presented in this study offer new insights regarding the importance of large-scale atmospheric circulation and water vapor transport as drivers of extreme flooding in the eastern part of Europe and could lead to a better flood forecast and flood risk management.
\end{abstract}

Keywords: floods; atmospheric circulation; impact; Siret River; Prut River

\section{Introduction}

Floods represent the most widespread natural hazard on Earth, with losses of numerous human lives and material damage of large proportions. According to the United Nations Office for Disaster Risk Reduction (UNISDR), floods constitute up to $43 \%$ of the total natural hazards. Between 1995 and 2015, floods affected more than 2.3 billion people worldwide and killed more than 200,000, while the total damage costs were estimated at more than 558 billion Euro [1]. Globally, there is an increasing trend, in the damages caused by floods, the main causes being the irrational use of the valley's rivers by deforestation, increasing economic activity on territories at risk, and global warming [1]. Moreover, there is a clear indication that these factors will contribute to the further growth of destructive frequency and power of floods [1]. The future climate projections have already warned of a possible increase in extreme rainfall events which will lead to more frequent and more extreme floods events. Under high-end climate scenarios (e.g., an increase of $4{ }^{\circ} \mathrm{C}$ in the global mean temperature by the end of the 21st century), climate change could triple the direct damages from floods during the 21st century, if no adaptation measures are taken. In their study, Alifieri et al. (2017) [2] have shown that with a temperature increase of $2{ }^{\circ} \mathrm{C}$, the related flood damages would rise by $170 \%$ compared to present levels, while for a $4{ }^{\circ} \mathrm{C}$ temperature increase globally, countries representing $73 \%$ of the global population would face a $580 \%$ increase in flood risk. That's why the task of elaboration of the flood management plan is paramount to real flood prevention and protection against them. 
The flood risks and vulnerability in Europe are similar to the worldwide situation. Only in the last 20 years, in Europe were recorded more than 400 major floods (many of them catastrophic), which affected more than 8.7 million people, killed more than 2000, and led to monetary losses of more than 72 billion Euro [3]. However, the high flood risk zones are not uniformly spread in Europe [4]. Throughout the last decades, Europe has been affected by a large number of flood events corroborated with heavy rainfall. Among the most costliest and damaging floods, over different parts of Europe, we have the following: the 1993 and 1995 winter floods in Germany, Netherlands, and France [5-8]; the 2002 and 2013 damaging floods in the Elbe River catchment area [9-11]; the 2005, 2008, and 2010 floods in the eastern part of Europe [12-14]; the 2010 floods in central part of Europe [15], and the 2000, 2007, and 2014 floods in U.K. [16-19]. Overall, at the European level, one of the most affected countries by extreme flooding is Romania (www.emdat.be, accessed on 23 November 2020). In 2005, 2006, 2008, 2010, 2014, and 2020, large-scale floods with catastrophic effects were recorded. According to the study conducted by DG Environment in 2014 at the European level, 20 major flood events took place in Romania between 2002 and 2013, during which 183 fatalities were recorded, more than 68,000 people were evacuated, and the total cost was estimated at $\approx 4.1$ billion Euro [20]. At the country level, one of the most affected regions by recurrent flooding is the northeastern part of Romania, floods being a permanent feature for the Siret and Prut basins. Throughout the last decades, several severe floods were recorded in Siret basin (e.g., 1970, 1991, 5002, 2006, 2008, and 2010) and Prut basin (1969, 1974, 1980, 2006, 2008, 2010, and 2020), with enormous material, human, and environmental damages.

One of the main factors of flood formation in the Siret and Prut Rivers catchment areas are heavy torrential rains that usually take place during the spring and summertime, especially in the upper part of the Siret and Prut River basins (Ukrainian territory), which leads to a rapid increase of streamflow and water levels over the tributaries, thus causing rapid flood peaks, which in turn form flood waves on the main rivers. Under these conditions, prevention and preparedness measures, as well as rapid intervention actions during the flood event, play a key role in the resulting flood consequences' magnitude and their mitigation. Flood risk management decisions and flood forecasting depends strongly on our understanding of the large-scale drivers of hydrological variability [21-24]. In this respect, the magnitude, timing, and the duration of extreme flood events and heavy rainfall depends on the hydroclimatic variability on different time scales ranging from hourly, daily, seasonal to interannual $[8,25,26]$. This variability is connected to the large-scale moisture transport on the entire atmospheric column, which in turn is controlled by different largescale teleconnection patterns such as the North Atlantic Oscillation (NAO), the Pacific North American Oscillation (PNA), and El Niño-Southern Oscillation (ENSO) [27,28].

Increased flood risk on the Siret and Prut river basin over the last decades, which was marked by the most severe floods in the last 80 years, caused significant economic damages and even losses of human lives, raising the issue of the urgent necessity of a suitable management plan adapted to local conditions and particularities based on explicit analyses of the previous extreme flood events. Therefore, the aim of this study is to do a comparative analysis of the most severe floods on the Siret and Prut Rivers, trying to disentangle their large-scale drivers and make an evaluation of their socio-economic impact. As the negative impacts of hydrological extremes are increasing in large parts of the world, better understanding of the drivers of changes in risk is essential for effective risk management and climate adaptation [29]. In this respect, socio-hydrometeorological information for each flood event is included in this study in order to be able to enable the consideration of various hazard, exposure and vulnerability aspects, the large-scale drivers as well as the broader context and specificities of the affected location. We focused our study on the Siret and Prut basins, because these are some of the most vulnerable areas for floods in the eastern part of Europe, and because no detailed studies regarding the large-scale drivers of extreme floods is currently available over this region. In this respect, the objectives of this study are manifold: (i) to analyze from a hydrological point of view 
(e.g., daily hydrographs and flood magnitude) three of the most damaging floods in the Siret and Prut catchment areas (July 2008, June-July 2010, and June 2020); (ii) to analyze the large-scale circulation preceding these extreme flood events; and (iii) to give a detailed overview of the socio-economic losses caused by these flood events and of the status of flood risk management plan implementation for these two-catchment areas. An in-depth understanding of the physical mechanism leading to extreme flooding and heavy rainfall event could help us in the quest for better predictability and impact assessment of future flood events.

The outline of the study is as follows. The basic features of the Prut and Siret catchment areas and the data and methods are described in Section 2. The main results are shown in Section 3. Future perspectives are given in Section 4, while the discussion and the main conclusions of the paper are presented in Section 5.

\section{Data and Methods}

\subsection{Catchment Area Description and Data Sources}

\subsubsection{Siret River Basin}

Siret and Prut Rivers are situated in the northeastern part of Romania, being among the most important tributaries of the Danube River (Figure 1). The Siret River drains a catchment area of $46,289 \mathrm{~km}^{2}, 90 \%$ of it being on the Romanian territory, and $10 \%$ on the territory of Ukraine. With a length of $599 \mathrm{~km}$, the Siret River is the 5th longest tributary of the Danube River [30]. The Siret springs are situated in the northeastern part of the Carpathian Mountains, on the territory of Ukraine; at around 1250 masl, it crosses the Moldavian Plateau, and then it flows southward until its confluence with the Danube River near Galati city (55 masl), at only $155 \mathrm{~km}$ from Danube Delta in the Black Sea. The large surface of the Siret hydrographic space implies a great variety of all the elements of the physical-geographical framework. The mountainous region is characterized by a rich runoff, and the plateau area is important for the strong torrential character of the runoff. All the main tributaries of the Siret River are located on the right side and originate from the Carpathian Mountains (e.g., Suceava, Șomuzurile, Moldova, Bistrița, Trotuș, Putna, Râmnicu Sărat and Buzău), except for the Bârlad River, which is the main left tributary, and it originates in the Moldavian Plateau [30].

The climate of the Siret basin is temperate with continental influences, but due to the large catchment area and the different relief units, it varies from cold and humid in the mountain regions, to warm and dry in the Moldavian Plateau and to hot and very dry climate downstream. Therefore, the annual mean temperature and precipitation vary from $\approx 2{ }^{\circ} \mathrm{C}$ and $1200 \mathrm{~mm}$ in the mountain area, to $\approx 8^{\circ} \mathrm{C}$ and $600 \mathrm{~mm}$ in the hilly and plateau parts, and to $\approx 10^{\circ} \mathrm{C}$ and $450 \mathrm{~mm}$ in the downstream plains [30]. 


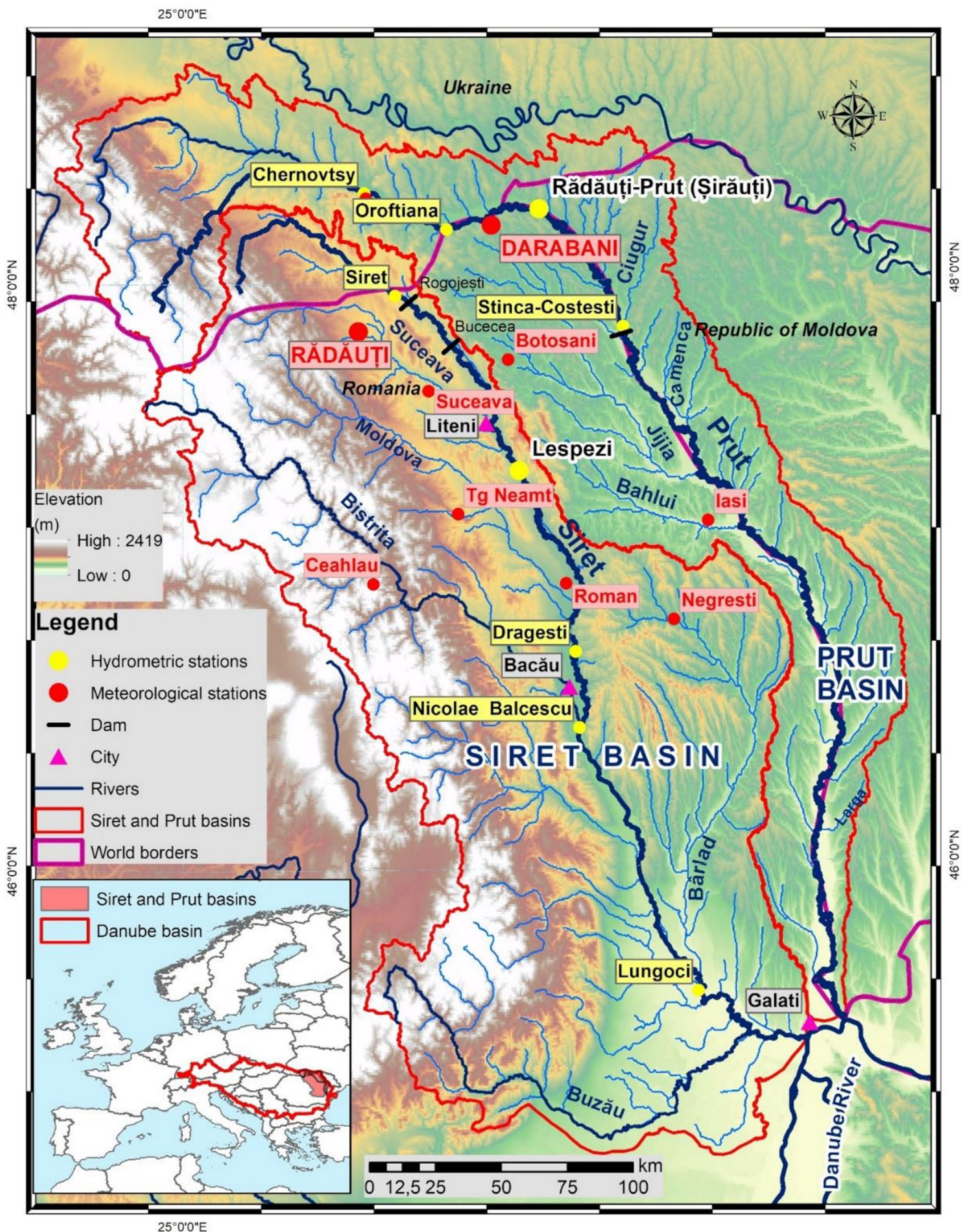

Figure 1. Location of the Siret and Prut catchment areas and the location of the gauging and meteorological stations used in this study.

\subsubsection{Prut River Basin}

The Prut River basin is located in the northeastern extremity of the Danube basin and drains an area of $28,568 \mathrm{~km}^{2}, 29 \%$ of which is on the territory of Ukraine, $39 \%$ is on the Romanian territory, and $32 \%$ is on the territory of the Republic of Moldova. The Prut basin borders the Siret basin to the west, the Tisza basin to the northwest, and the Dniester basin to the north and east. With a length of $953 \mathrm{~km}$, the Prut River is the third-longest Danube tributary [30,31]. The Prut River originates in the southwestern part of the Ukrainian Carpathians at 1600 masl, and it flows for the first $211 \mathrm{~km}$ eastwards in Ukraine, after which for $31 \mathrm{~km}$ it forms the border between Romania and Ukraine, while for the next $711 \mathrm{~km}$, it forms the border between Romania and the Republic of Moldova and discharges into the Danube River at only $132 \mathrm{~km}$ from Danube mouth [30]. Similar to Siret's main 
relief units, the Prut catchment area can be divided into a mountain region ( $20 \%$ of total basin surface), hills ( $12 \%$ of total basin surface), and lowlands (68\% of total basin surface).

The main tributaries of the Prut River on the right side are Volovăț, Bașeu, Jijia, Elan and Chinja, while on the left side, the main tributaries are Larga, Ciugur, Camenca, Gârla Mare, and Delia [30]. The climate of the Prut River basin has similar characteristics as the Siret basin, with a moderate mild continental climate in the upper section and a harsher continental climate in the lower section. The annual mean temperature and precipitation vary from $\approx 2{ }^{\circ} \mathrm{C}$ and $1400 \mathrm{~mm}$ in the mountain area to $\approx 9^{\circ} \mathrm{C}$ and $400-600 \mathrm{~mm}$ in the lowland plains [30].

\subsection{Data}

The main variable analyzed in this study is the daily streamflow data at Lespezi (Siret River, Figure S1a) and Rădăuți-Prut (Prut River, Figure S1b) gauging stations. We also make use of the daily precipitation time series at Rădăuți meteorological station (Siret River) and Darabani meteorological station (Prut River). The daily streamflow data were made available by the Global Runoff Data Center (www.bafg.de, accessed on 14 October 2020) and the data for 2020 have been downloaded from the website of the National Institute of hydrology and Water management in Romania (www.inhga.ro, 15 November 2020). This study is focused on three extreme flood events, namely July 2008, June-July 2010, and June 2020. The date of occurrence and magnitude of the three flood events are given in Table 1. The daily precipitation data have been extracted from the E-OBS database v22.0 [32]. For the large-scale atmospheric circulation, we use the daily sea level pressure (SLP), zonal and meridional wind, geopotential height at $500 \mathrm{mb}$ level (Z500), potential vorticity (PV), air temperature at $850 \mathrm{mb}$ level (TT850), specific humidity, and surface pressure from the ERA5 Reanalysis data [33]. The gridded daily precipitation totals were extracted also from the ERA Reanalysis data. ERA5 is produced using 4D-Var data assimilation in CY41R2 of ECMWF's Integrated Forecast System (IFS), with 137 hybrid sigma/pressure (model) levels in the vertical, with the top-level at $0.01 \mathrm{hPa}$. Atmospheric data are available on these levels, and they are also interpolated to 37 pressure, 16 potential temperature, and 1 potential vorticity level(s). The output of this reanalysis product is a $4 \mathrm{D}$ global atmospheric dataset spanning from 1979 up to the present period. The resolution of the data set is $\approx 0.25^{\circ} \times 0.25^{\circ}[33]$.

Table 1. Maximum streamflow recorded at different hydrometric station on Siret and Prut Rivers for 2008, 2010, and 2020 floods, and their total economic damages.

\begin{tabular}{|c|c|c|c|c|}
\hline & & 2008 & 2010 & 2020 \\
\hline River Basin & Hydrometric Station & Streamflow $\left(\mathrm{m}^{3} / \mathrm{s}\right) /$ Date & Streamflow $\left(\mathrm{m}^{3} / \mathrm{s}\right) /$ Date & Streamflow $\left(\mathrm{m}^{3} / \mathrm{s}\right) /$ Date \\
\hline Siret & Siret & 920/25 July & 1115/29 June & - \\
\hline Siret & Lespezi & 1793/27 July & 1719/29 June & 640/24 June \\
\hline Siret & Drăgești & 2930/27July & 2058/30 June & - \\
\hline Siret & Nicolae Bălcescu & 2200/28July & 1339/01 July & - \\
\hline Suceava & Itcani & 1710/26July & 883/29 June & - \\
\hline Prut & Chernovtsy & 3890/25July & - & 1490/24 June \\
\hline Prut & $\begin{array}{l}\text { Rădăuți-Prut } \\
(\text { (Șirăuț *) }\end{array}$ & 4033/28 July & * 1930/02 July & 2920/26 June \\
\hline \multirow[t]{3}{*}{ Prut } & $\begin{array}{c}\text { Stânca-Costești } \\
\text { downstream }\end{array}$ & 1400/31 July & 800-830/01 July & $680 / 26$ June \\
\hline & & \multicolumn{3}{|c|}{ Total economic damages } \\
\hline & & more than 2 billion Euro & more than 1 billion Euro & rhalf of billion Euro \\
\hline
\end{tabular}

\footnotetext{
* Indicates that there are two different gauging stations.
} 


\subsection{Methods}

In order to analyze the flood peaks for each event, we have used the daily hydrographs Lespezi gauging station (Siret River) and Rădăuț-Prut gauging station (Prut River) and the daily precipitation totals at the meteorological station in the near vicinity of the gauging stations (Radauti meteorological station for Siret River and Darabani meteorological station for Prut River, see Figure 1). For the large-scale atmospheric circulation, we have used daily snapshots, up to 10 days prior to each flood peak until the day of the flood peak, for the different large-scale variables: the potential vorticity PV at $330 \mathrm{~K}(\mathrm{PV})$, the daily geopotential height at $500 \mathrm{mb}$ (Z500), and the daily mean air temperature at $850 \mathrm{mb}$ (TT850). The vertically integrated water vapor transport (WVT) [34] is calculated through zonal wind (u), meridional wind (v), and specific humidity (q), from the ERA5 Reanalysis data [33]. The WVT vectors for latitude $(\phi)$ and longitude $(\lambda)$ are defined as follows:

$$
\vec{Q}(\lambda, \varphi, t)=Q_{\lambda} \vec{i}+Q_{\varphi} \vec{j}
$$

where zonal $\left(Q_{\lambda}\right)$ and meridional $\left(Q_{\Phi}\right)$ components of $Q$ are given by:

$$
\begin{aligned}
& Q_{\lambda}=-\int_{1000}^{p} q u \frac{d p}{g} \\
& Q_{\phi}=-\int_{1000}^{p} q v \frac{d p}{g}
\end{aligned}
$$

where $u$ is the zonal wind component, $v$ is the meridional wind component, $q$ is the specific humidity, $p$ is the desired pressure $(\mathrm{hPa})$ up to which the atmospheric parameters are integrated, and $g$ is the gravitational constant.

\section{Results}

\subsection{July 2008 Flood Event}

\subsubsection{Hydrological Situation}

In the upper part of the Siret and Prut River basins, the July precipitation norm is on average $\approx 100 \mathrm{~mm}$, while the daily rainfall rarely exceeds $20 \mathrm{~mm} /$ day. An exceptional case was recorded in July 2008, when an amount twice and a half more than the norm was recorded, half of which was recorded during two days: 24 and 25 July 2008, respectively (Figure 2). At Rădăuți (Darabani) meteorological stations situated in the upper part of the Siret (Prut) River basins, a rainfall amount of $252 \mathrm{~mm}(183 \mathrm{~mm})$ was recorded in July 2008, while the norm for this month is $103 \mathrm{~mm}(84 \mathrm{~mm})$.

On the 25th of July 2008, record-breaking daily rainfall amounts were observed both at Radauti meteorological station (70.84 mm, Figure S2a) as well as at Darabani meteorological station (56.34 mm, Figure S3a). Heavy rainfall was recorded also at other meteorological stations in the catchment areas of the two analyzed rivers (Table S1). The exceptional heavy rainfall over the period 24-26 July 2008 was followed by the largest floods, in terms of magnitude, which occurred on the upper section of the Siret and Prut Rivers (including the most important tributaries), over the observational period. Usually, the flood peak follows 2-3 days after heavy rainfall events upstream.

The July 2008 flood on the Siret River had a regional character, with catastrophic consequences in Ukraine and in the northern part of Romania of the river catchment, between Liteni (confluence with the Suceava River) and Bacău. Although the highest rainfall amount felt on the Ukrainian territory at the entrance on the Romanian territory, the streamflow of the Siret River, at Siret hydrometric station, reached a value of $920 \mathrm{~m}^{3} / \mathrm{s}$, which is twice and a half more than the danger level [35,36]. Downstream of the Siret hydrometric station, the flood wave was attenuated by the Rogojesti and Bucecea dams. 

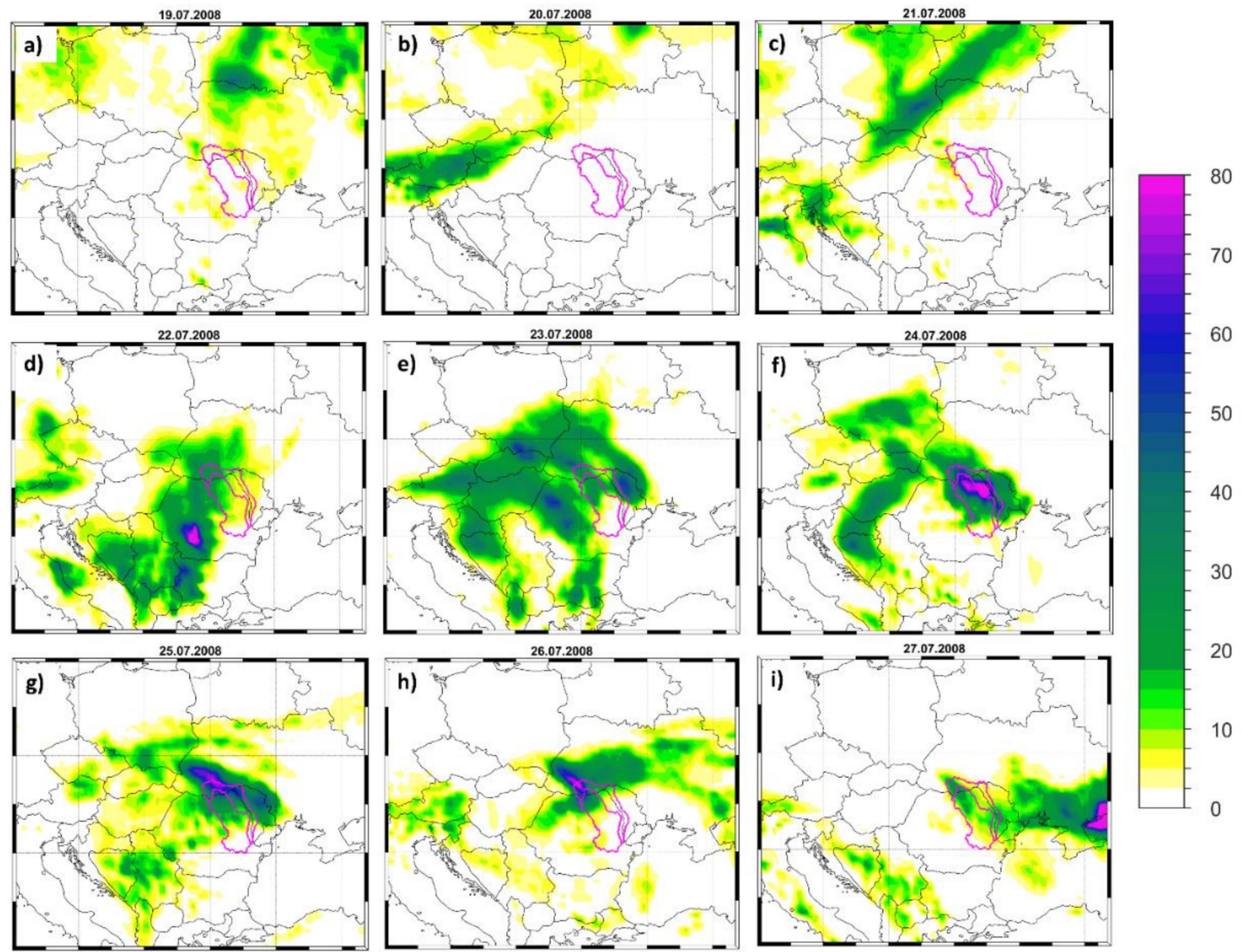

Figure 2. Daily precipitation totals (PP) for: (a) 19 July 2008; (b) 20 July 2008; (c) 21 July 2008; (d) 22 July 2008 ; (e) 23 July 2008; (f) 24 July 2008; (g) 25 July 2008; (h) 26 July 2008, and (i) 27 July 2008. Units: PP (mm/day).

The catastrophic floods on the Siret River, downstream of the confluence with the Suceava river were strongly influenced by the water input from the tributaries, which also recorded historic streamflow rates (Suceava $=1710 \mathrm{~m}^{3} / \mathrm{s}$ and Moldova $=696 \mathrm{~m}^{3} / \mathrm{s}$ ) [36]. At Lespezi hydrometric station (situated downstream of the Suceava River), the streamflow started to rise on the 24th of July and reached the maximum flood peak on $27 \mathrm{July}$, when a streamflow of $1793 \mathrm{~m}^{3} / \mathrm{s}$ was recorded. After the maximum of the flood peak, the streamflow started to decrease, reaching again a level below the danger limit on the 30th of July (Figure 3a). The propagation of the flood wave downstream on the Siret River led to record streamflow values at Nicolae Bălcescu $\left(2200 \mathrm{~m}^{3} / \mathrm{s}\right)$ and Drăgesti $\left(2930 \mathrm{~m}^{3} / \mathrm{s}\right)$ hydrometric stations. At the Lespezi and Nicolae Bălcescu hydrometric stations, the streamflow values from 2008 are more than double the maximum values from the entire previous monitoring period.

On the Prut River, the July 2008 flood event occurred according to a scenario similar to the one observed for the Siret River, but the flow parameters and the flood wave propagation were different. On the 24th and 25th of July, heavy rainfall events occurred in the upper and middle parts of both river basins (Figure 3, Table S1). The daily streamflow on the Prut River started to rise on the 24th of July, when at Chernovtsy hydrometric station, exceptional streamflow values were recorded, as a consequence of the heavy rainfall. The daily streamflow continued to rise very fast until the 27th of July when a flood peak of $3890 \mathrm{~m}^{3} / \mathrm{s}$ was recorded [37]. A similar situation was recorded also at Oroftiana and Rădăuți-Prut hydrometric stations. At Rădăuți-Prut hydrometric station, on the 24th of July, a streamflow of $217 \mathrm{~m}^{3} / \mathrm{s}$ has recorded, which was three times higher than the day 
before, and it continued to rise until the 28th of July, when the maximum peak of the flood $\left(\approx 4033 \mathrm{~m}^{3} / \mathrm{s}\right)$ was recorded, after which the streamflow started to decrease, reaching a value of $349 \mathrm{~m}^{3} / \mathrm{s}$ on the 1 st of August (Figure 3b). The flood wave propagated downstream of Rădăuți-Prut gauging station with similar intensity until the Stânca-Costești lake, which played a decisive role in mitigating the flood wave. The Stânca-Costești dam, with a capacity of $\approx 1300$ mil. $\mathrm{m}^{3}$ of water, took over and attenuated the impact of the flood wave. The water discharge from Stânca-Costesti Lake was carried out with a streamflow of $\approx 620 \mathrm{~m}^{3} / \mathrm{s}$ since the 24th of July (up to six times higher than before the flood began), and $\approx 1400 \mathrm{~m}^{3} / \mathrm{s}$ since the 31st of July [37]. The increase of water discharge was carried out as a result of the exceptional increase of the water volume, approaching the maximum limit of the dam. As a consequence of this decision, some localities downstream of Stânca-Costești were flooded.

(a)

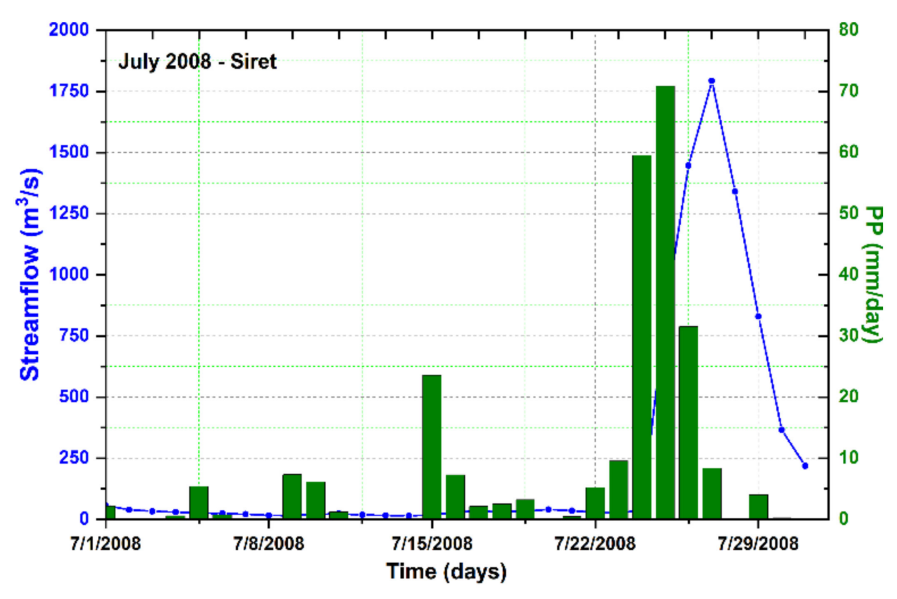

(c)

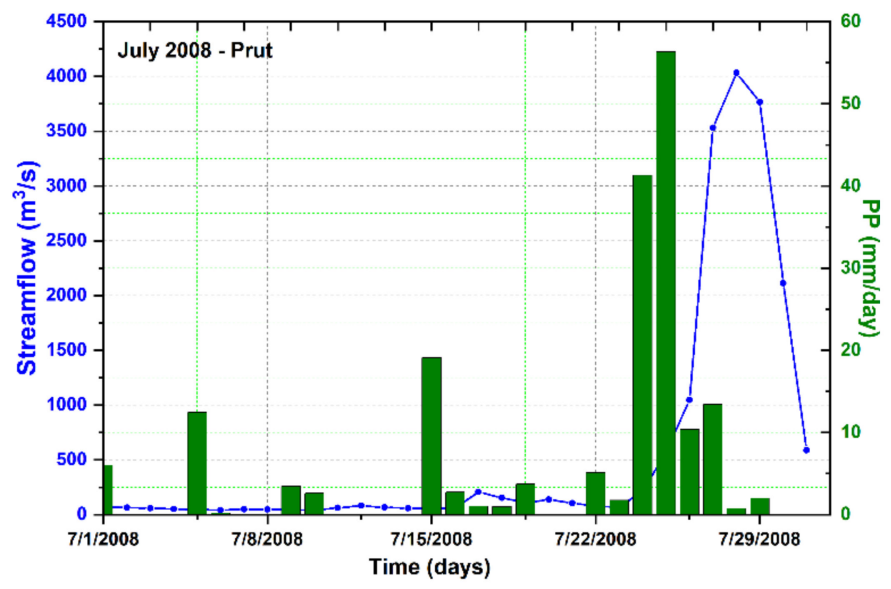

(b)

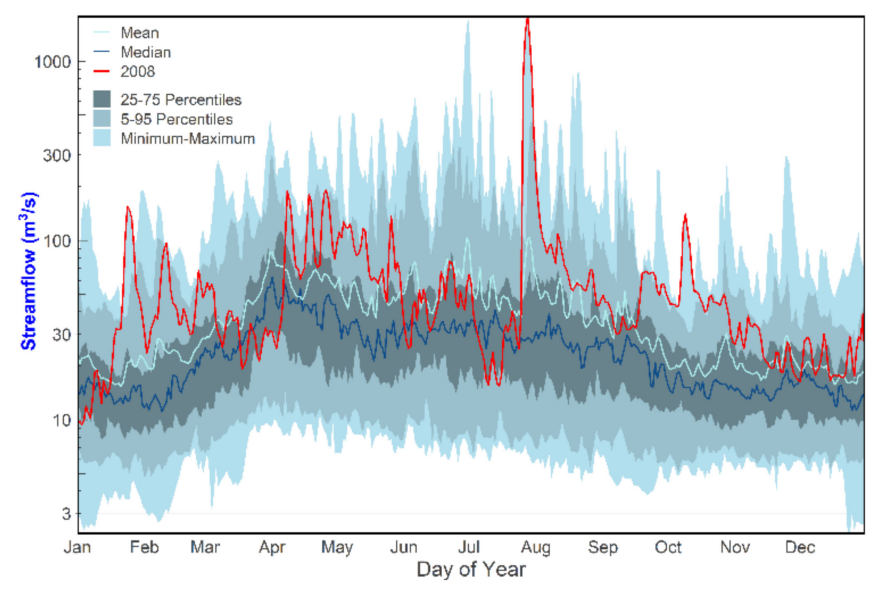

(d)

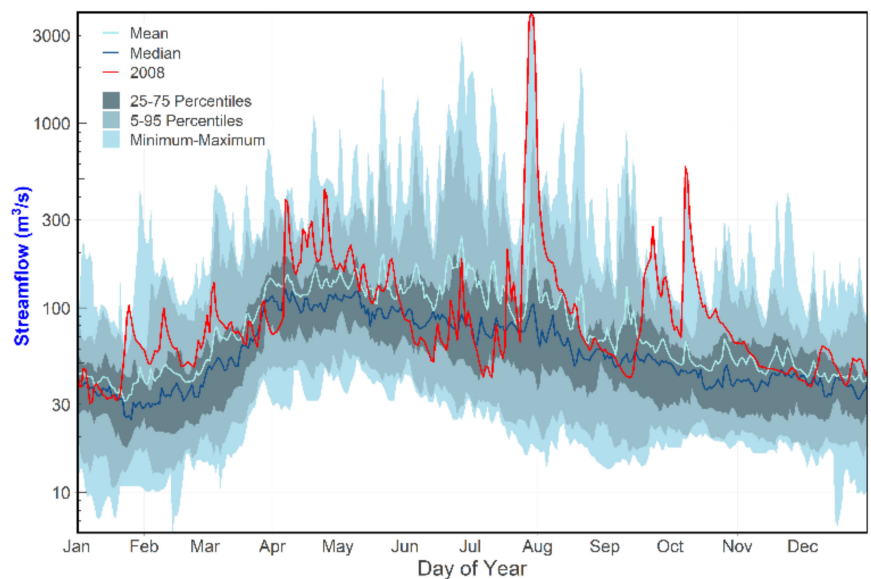

Figure 3. (a) Daily streamflow at Lespezi gauging station situated on the Siret River (blue line) and the precipitation amount at Rădăuți meteorological station (green bars) for the period 1 July-31 July2008; (b) The evolution of the flood peak in July 2008 (red line) at Lespezi gauging station compared to the daily streamflow pattern on an annual basis (blue shaded line); (c) Daily streamflow at Rădăuț-Prut gauging station situated on the Prut River (blue line) and the daily precipitation amount at Darabani meteorological station (green bars) for the period 1 July-31 July 2008 and (d) The evolution of the flood peak in July 2008 (red line) at Rădăuți-Prut gauging station compared to the daily streamflow pattern on an annual basis (blue shaded area). For the location of the gauging and meteorological stations; see Figure 1. The period 1981-2000 was used to compute the daily streamflow climatology in $(\mathbf{b}, \mathbf{d})$. 


\subsubsection{Atmospheric Conditions}

The extreme rainfall and the associated flood events in July 2008 were preceded by particular large-scale atmospheric circulation patterns at European scale (Figures 4 and 5). During the 19-27 July 2008 period, the days with extreme precipitation events were associated with inter water vapor transport (WVT). The WVT reached a magnitude of $\approx 250 \mathrm{~kg} \mathrm{~m}^{-1} \mathrm{~s}^{-1}$ (and exceeded values of $350 \mathrm{~kg} \mathrm{~m}^{-1} \mathrm{~s}^{-1}$ between 23rd and 25th of July) over both Siret and Prut catchment areas, with the highest recoded values over Ukraine (Figure 4). The synoptic evolution of the tropopause level flow, prior to the flood peaks, is analyzed by using the dynamical tropopause on the $330 \mathrm{~K}$ isentropic level. Previous studies have shown that heavy rainfall and floods are linked with the upper level through being associated with the presence of elongated intrusions of air the so-called PV streamers $[8,27,38]$. Southward intrusions of air with high PV in the lower stratosphere or the higher troposphere are associated with the lowering of the dynamical tropopause, leading to vertical motions, cyclogenesis, and heavy rainfall. The days before the flood peak from July 2008 in the Siret and Prut River basins were associated with high PV values over the eastern part of Europe (Figure 5f-i). The temporal evolution and the spatial structure of the potential vorticity field indicate that in the days prior to the flood peak, a cut-off low was present over the central part of Europe moving eastward. The axis of the WVT (Figure 4) follows the non-linear behavior of the potential vorticity field. Positive upper level PV anomalies have the tendency to affect the structure of the atmosphere below them [39]. This is visible also in the case of the July 2008 flood events, when the high PV values over the eastern part of Europe observed between the 23rd and 27th of July were associated with a pivotal cut-off low that lasted for 4 days (Figure 5e-h) and warm air advection over the southeastern part of Romania and cold air advection over the northern part of our analyzed region (Figure S4), which led to heavy rainfall events over the Prut and Siret catchment areas.
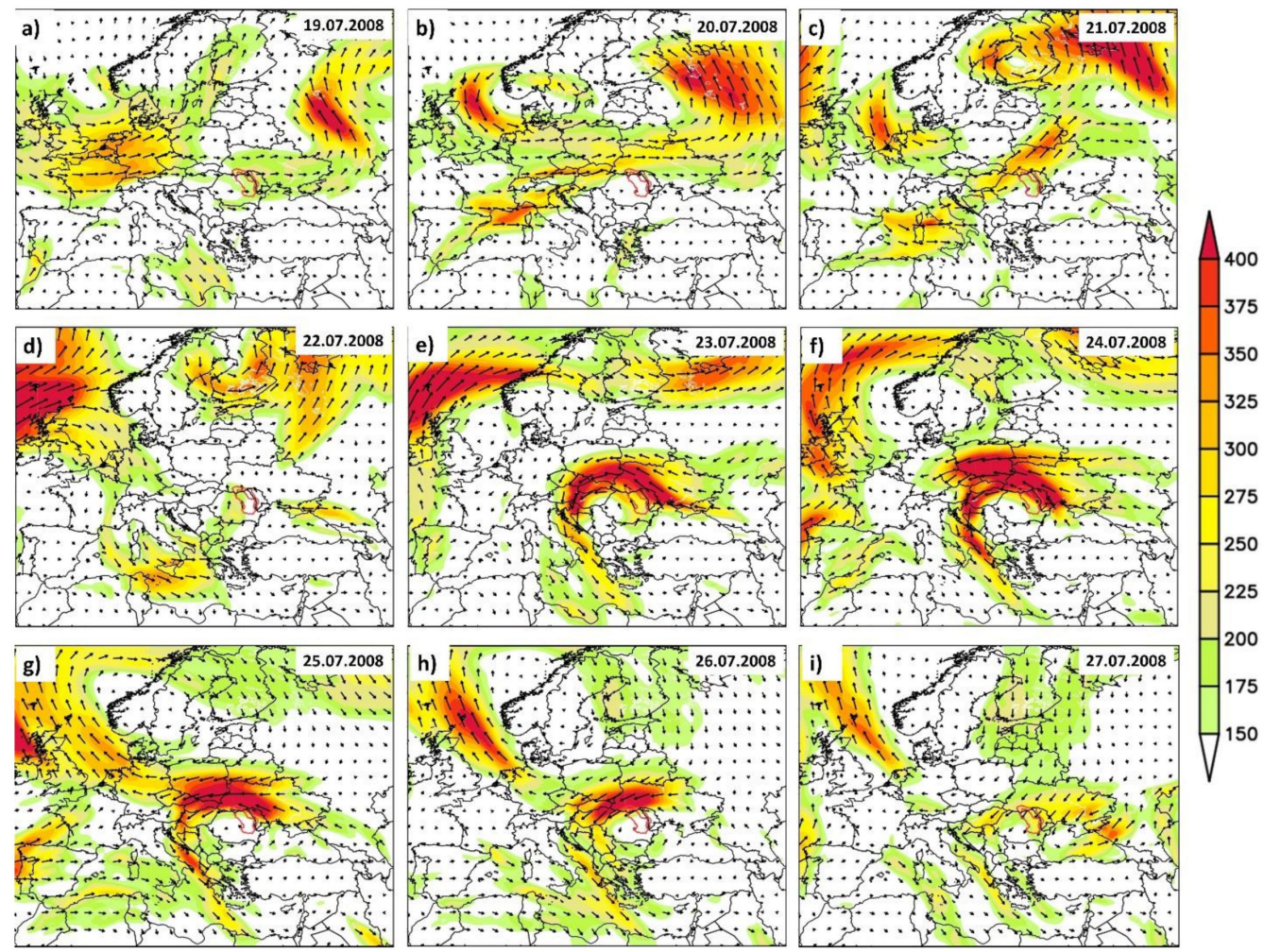

Figure 4. Magnitude (shaded colors) and direction (vectors) of the daily integrated water vapor transport (WVT) for: (a) 19 July 2008; (b) 20 July 2008; (c) 21 July 2008; (d) 22 July 2008; (e) 23 July 2008; (f) 24 July 2008; (g) 25 July 2008; (h) 26 July 2008 , and (i) 27 July 2008. Units: WVT $\left(\mathrm{kg} \cdot \mathrm{s}^{-1} \cdot \mathrm{m}^{-1}\right)$. 

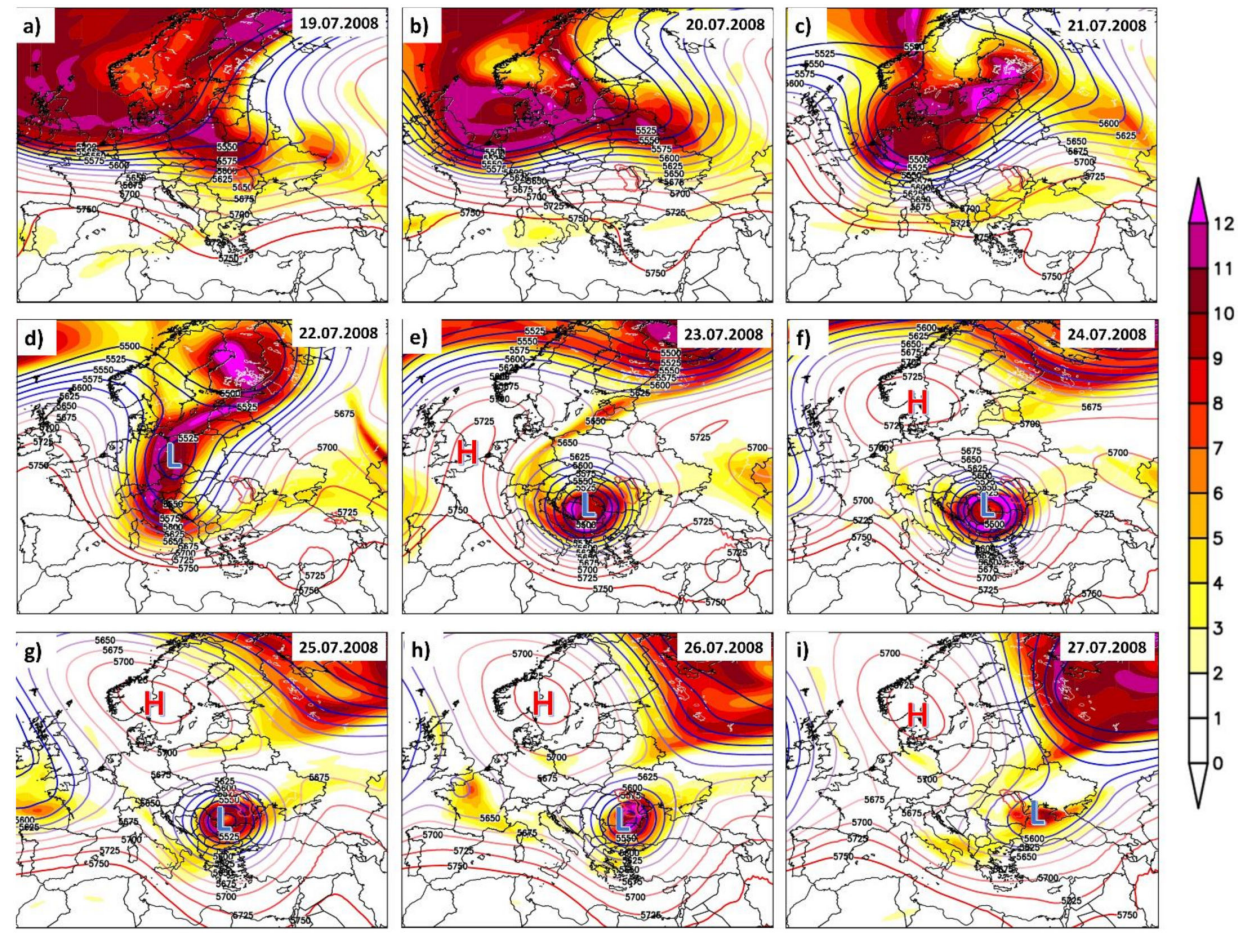

Figure 5. Daily potential vorticity (PV) at $330 \mathrm{~K}$ (shaded colors) and daily geopotential height at $500 \mathrm{hPa}$ (Z500) (contour lines) for: (a) 19 July 2008; (b) 20 July 2008; (c) 21 July 2008; (d) 22 July 2008; (e) 23 July 2008; (f) 24 July 2008; (g) 25 July 2008 ; (h) 26 July 2008, and (i) 27 July 2008. Units: PV (PVU) and Z500 (m). L (blue) denotes low pressure system and H (red) denotes high pressure systems.

\subsubsection{Socio-Economic Impact of July 2008 Flood Event}

The extreme flood peaks from July 2008, from the upper part of Siret and Prut Rivers, led to important socio-economic losses with catastrophic consequences. These losses were due mainly to the high amplitude of the main parameters of the flood events (e.g., the peak flows and the drained volumes, respectively). During the July 2008 flood, numerous localities, agricultural lands, roads, and bridges on the territory of Ukraine, Romania, and the Republic of Moldova were affected. In Romania, the total value of the damages caused by the July 2008 flood was $\approx 2$ billion Euro [36]. Among the main objectives and destroyed assets we mention 7 deceased persons, over 30,000 affected people, 150 damaged villages, 67,500 damaged or destroyed houses, 313 damaged annexes and 24 socio-economic objectives, 1246 bridges and footbridges damaged or destroyed, $\approx 1900 \mathrm{~km}$ of national and country roads, and 345 of railway road affected. Other damaged goods include $49 \mathrm{~km}$ of canals, $355 \mathrm{~km}$ of dikes, $94.13 \mathrm{~km}$ of bank defenses and dams, $55.4 \mathrm{~km}$ of drainage channels, $110 \mathrm{~km}$ of anti-erosion works, 5 dams, 10 micro hydropower plants, 27 hydrometric stations, more than 49,000 ha of agricultural land, $1.68 \mathrm{~km}$ of water supply networks, $37.2 \mathrm{~km}$ of sewerage networks, $234.8 \mathrm{~km}$ of electricity networks, $1.6 \mathrm{~km}$ of natural gas supply networks, $6.1 \mathrm{~km}$ of riverbed clogging and erosions, $30 \mathrm{~km}$ of water supply pipes destroyed, and 1.500 flooded fountains $[35,40,41]$.

In the Republic of Moldova, the exceptional flood from June 2008 (on Prut and Dniester rivers) caused material damages of $\approx 101.5$ million Euro. In addition, three people died, thousands of people were affected, 8473 ha of agricultural land and 1183 houses were damaged, 3000 fountains were flooded, and more than 3000 domestic animals died [37,42]. Over western Ukraine, the 2008 flood damages were estimated at $\approx 548-733$ million Euro by ONU [43] with the following reported socio-economic losses/damages: 37 dead people, over 45,000 houses from 784 localities, 30,000 hectares of agricultural land, $700 \mathrm{~km}$ of roads, and over 350 bridges [42-44]. 


\subsection{June-July 2010 Flood Event}

\subsubsection{Hydrological Situation}

Similar to climatic conditions during the July 2008 flood, the June-July 2010 flood event was preceded by exceptionally heavy rainfall, but unlike the 2008 flood when high rainfall amounts were recorded throughout few consecutive days, in June 2010, heavy rainfall fell in repeated cycles of two days over the period 21 June-2 July 2010, which in turn led to several flood peaks on the most important tributaries of Prut and Siret Rivers. High rainfall amounts were recorded both in June and July 2010, over the western part of Ukraine, where the upper reaches of the Siret and Prut Rivers are located (Figure 6). The precipitation amount that felt during this period was $50-80 \%$ of the annual norm, exceeding $1.5-2$ times the multiannual average $[45,46]$. For example, at the Rădauți (Darabani) meteorological stations, over the May-June 2010 period, a rainfall amount of $403 \mathrm{~mm}(301 \mathrm{~mm})$ was recorded, while the annual norm for these months is $180 \mathrm{~mm}(144 \mathrm{~mm})$ (Figure 7). Locally, heavy and very heavy torrential rain exceeded $40 \mathrm{~mm}$ of precipitation in just a few hours (Figures S2b and S3b, Table S2).

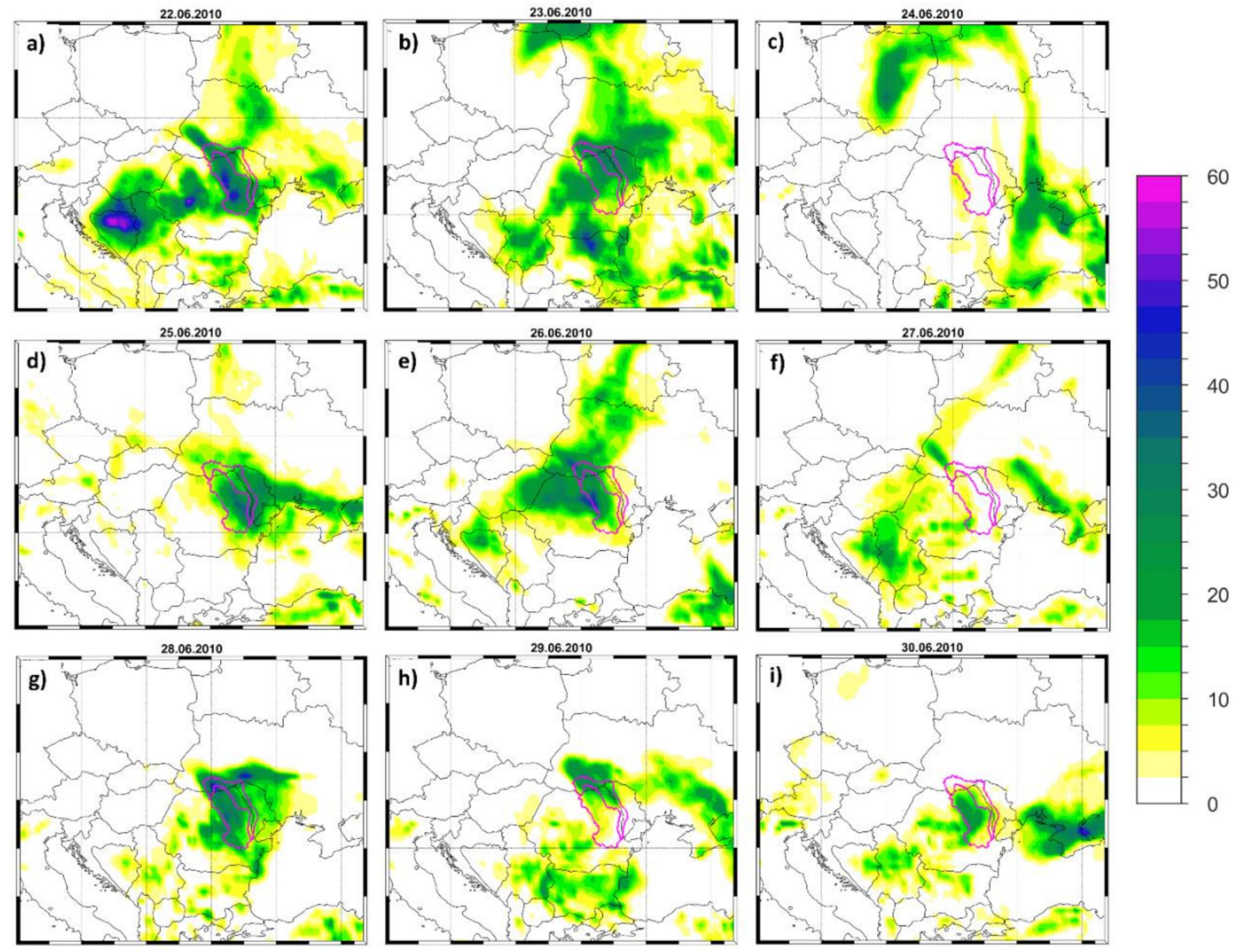

Figure 6. Daily precipitation totals (PP) for: (a) 22 June 2010; (b) 23 June 2010; (c) 24 June 2010; (d) 25 June 2010 ; (e) 26 June 2010; (f) 27 June 2010; (g) 28 June 2010; (h) 29 June 2010; and (i) 30 June 2010. Units: PP (mm/day).

The flood event from June 2010 had a complex character due to several cycles of flood waves that occurred on the important tributaries. The first cycle of precipitation fell between the 22nd and 23rd of June 2010 (Figure 6) and led to the formation of a flood wave of small proportions (Figure $7 \mathrm{a}, \mathrm{c}$ ). The second cycle occurred between the 25th and 26th of June 2010 (Figure 6), which led to an additional increase of the streamflow. As the soil was already saturated from the previous precipitation event, and due to the extreme rainfall recorded between the 28th and 30th of June 2010, the streamflow on the Siret River increased very rapidly and determined a catastrophic flood wave (Figure $7 \mathrm{a}, \mathrm{b})$. In the upper part of the Siret River, the maximum flood peak was recorded on 29 June, when 
at Siret hydrometric station, a record daily streamflow of $1115 \mathrm{~m}^{3} / \mathrm{s}$ was observed [47]. Nevertheless, the streamflow decreased downstream until the confluence with the Suceava River due to the lakes on the main course of the river. The exceptional streamflow of $883 \mathrm{~m}^{3} / \mathrm{s}$ on the 29th of June 2010, which was recorded at Itcani hydrometric station (Suceava river), contributed to the propagation of the flood wave downstream on the Siret River. On the 29th of June 2010, an exceptional high streamflow was recorded at Lespezi hydrometric station $\left(1205 \mathrm{~m}^{3} / \mathrm{s}\right)$ and continued to grow until the 1st of July 2010, when a flood peak of $1719 \mathrm{~m}^{3} / \mathrm{s}$ was recorded. After this flood peak, the streamflow started to decrease, reaching again an average streamflow for this period on the 3rd of July 2010 (Figure $7 \mathrm{a}, \mathrm{b}$ ). The influence of flood peaks from the tributaries on the propagation of the flood wave on the main river was observed at Drăgești hydrometric station, situated downstream of the confluence with Moldova river, where a record streamflow of $2058 \mathrm{~m}^{3} / \mathrm{s}$ was recorded on the on 30th of June 2010 [47]. High streamflow values were also recorded at Nicolae Bălcescu $\left(1339 \mathrm{~m}^{3} / \mathrm{s}\right)$ and Lungoci $\left(2576 \mathrm{~m}^{3} / \mathrm{s}\right)$ hydrometric stations on the 1st of July 2010 [47].

(a)

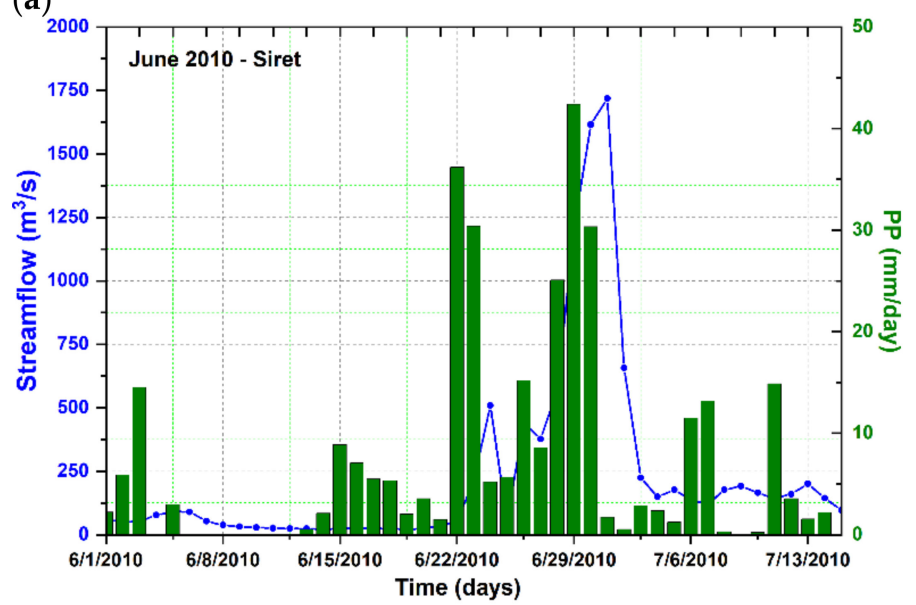

(c)

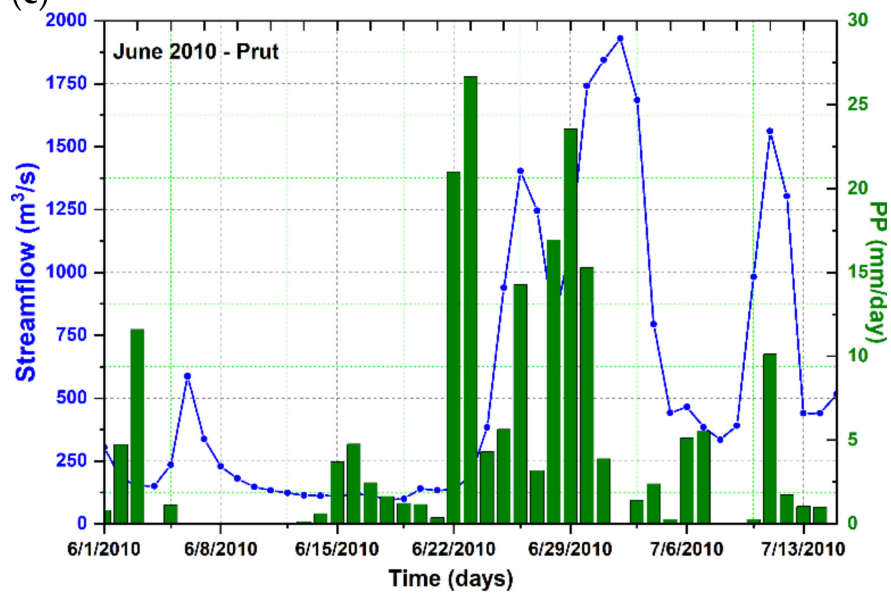

(b)

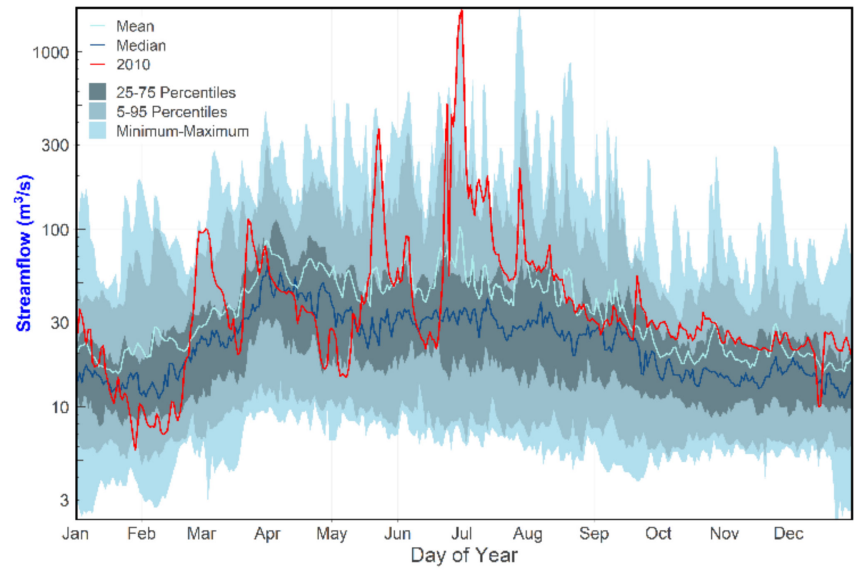

(d)

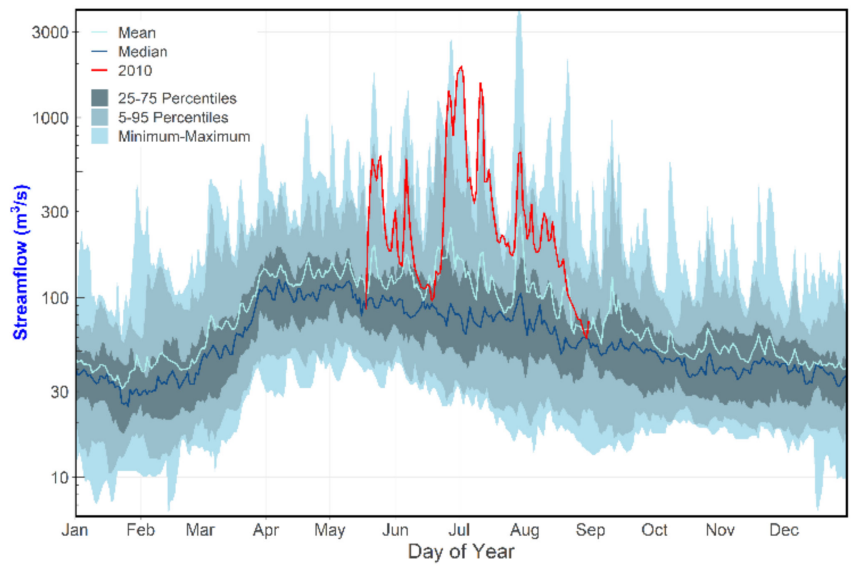

Figure 7. (a) Daily streamflow at Lespezi gauging station situated on the Siret River (blue line) and the precipitation amount at Rădăuți meteorological station (green bars) for the period 1 June-15 July 2010; (b) The evolution of the flood peak in June 2010 (red line) at Lespezi gauging station compared to the daily streamflow pattern on an annual basis (blue shaded line); (c) Daily streamflow at Rădăuți-Prut gauging station situated on the Prut River (blue line) and the daily precipitation amount at Darabani meteorological station (green bars) for the period 1 June-15 July 2010; (d) The evolution of the flood peak in June 2010 (red line) at Rădăuți-Prut gauging station compared to the daily streamflow pattern on an annual basis (blue shaded area). For the location of the gauging and meteorological stations, see Figure 1. The period 1981-2000 was used to compute the daily streamflow climatology in $(\mathbf{b}, \mathbf{d})$. For Rădăuți-Prut gauging station streamflow data was available just for the period 18 May-31 August 2010. 
The precipitation regime in June 2010 affected the Prut basin in a similar way as the Siret basin, but with specific features due to basin configuration. Unlike the Siret River, for which multiple flood peaks were recorded only on the important tributaries, on Prut River, the flood event had several peaks on the main course. The first catastrophic flood wave was recorded between the 26th and 27th of June 2010 (Figure 7c), after the second extreme precipitation event, when very high values of the streamflow were recorded at several hydrometric stations in the upper part of the Prut River, including Chernovtsy, Oroftiana, and Șirăuți. At Șirăuți hydrometric station the streamflow reached a value of $\approx 1400 \mathrm{~m}^{3} / \mathrm{s}$ on the 26th of June. The second flood wave at Șirăuti was recorded between 29th of June and 3rd of July 2010, with a maximum peak of $1930 \mathrm{~m}^{3} / \mathrm{s}$ on the 2nd of July 2010, after which the streamflow decreased up to $\approx 450 \mathrm{~m}^{3} / \mathrm{s}$ on the 5 th of July (Figure $7 \mathrm{c}$ ). The third flood wave was recorded between 10th and 11th of July 2010, when the streamflow increased rapidly again, reaching up to $\approx 1600 \mathrm{~m}^{3} / \mathrm{s}$. The flood wave downstream of the Stânca-Costești dam was controlled in order to reduce the flood impact. Starting with the 25th of June, the water from Stânca-Costești lake was evacuated with a streamflow of $427 \mathrm{~m}^{3} / \mathrm{s}$; on the 28th of June, it was raised to $618 \mathrm{~m}^{3} / \mathrm{s}$, and starting with the 1st of July, it was raised to a value of $\approx 800-830 \mathrm{~m}^{3} / \mathrm{s}$. The flow was increased due to the excessive increase in the volume of water in the lake, which was close to the upper limit of the lake's capacity, and it was maintained at this high level until 11th of July, after which the water discharge flow from the Stânca-Costeşti accumulation lake was decreased to $480 \mathrm{~m}^{3} / \mathrm{s}$ [45,48]. These measures caused the flooding of large areas downstream of the Stânca-Costești dam, as well as the extensive damages or breakage of other dams downstream.

\subsubsection{Atmospheric Conditions}

The extreme rainfall and the associated flood events in June 2010 were preceded also by particular large-scale atmospheric circulation patterns, such as in the case of the July 2008 event. Between the 22nd and the 30th of June 2010, the days with extreme precipitation events (Figure 6), were associated with intense water vapor transport toward the catchment area of both Prut and Siret Rivers (Figure 8). Between the 22nd and 26th of June, the water vapor transport was confined mainly over the northern part of the catchment area of Prut and Siret Rivers (Figure 8a-f), while between the 28th and 30th of June, the WVT was affecting the whole catchment area of the two rivers (Figure 8g-i). The heavy rainfall events in June 2010 were triggered by strong high PV anomalies over the analyzed region (Figure 9) and several pivoting low-pressure systems (Figure 9), which developed in cycles of two or three days. This happened in the context of a double blocking structure (simultaneous action of the European ridge on the west and east of the European Continent), as captured by the configuration of the geopotential at the level of $500 \mathrm{hPa}$ (Figure 9). As a result of this extreme blocking pattern, the low-pressure system remained relatively stationary (Figure 9e-i), so rainfall events were recorded over several days. Warm, moist air was pulled northward from the Black Sea to feed the storm system (Figure S5). The positive PV anomalies associated with cut-off lows, and the structure of the geopotential height anomalies at the $500 \mathrm{hPa}$ allowed the advection of warm air from the south-east and cold air from the north toward our analyzed region, leading to heavy rainfall events and as a consequence to extreme flooding over the Prut and Siret basins. Moreover, the combination of warm air from the southeast and cold air from the north led to amplification and persistence of the atmospheric blocking on the eastern side of our analyzed region for most of the period when the flooding occurred. As a result, the low-pressure systems that reached the Black Sea basin were enriched with large amounts of water vapor afterwards (Figure 8), which later led to the extreme rainfall events in the northern part of the catchment area of Prut and Siret Rivers. 

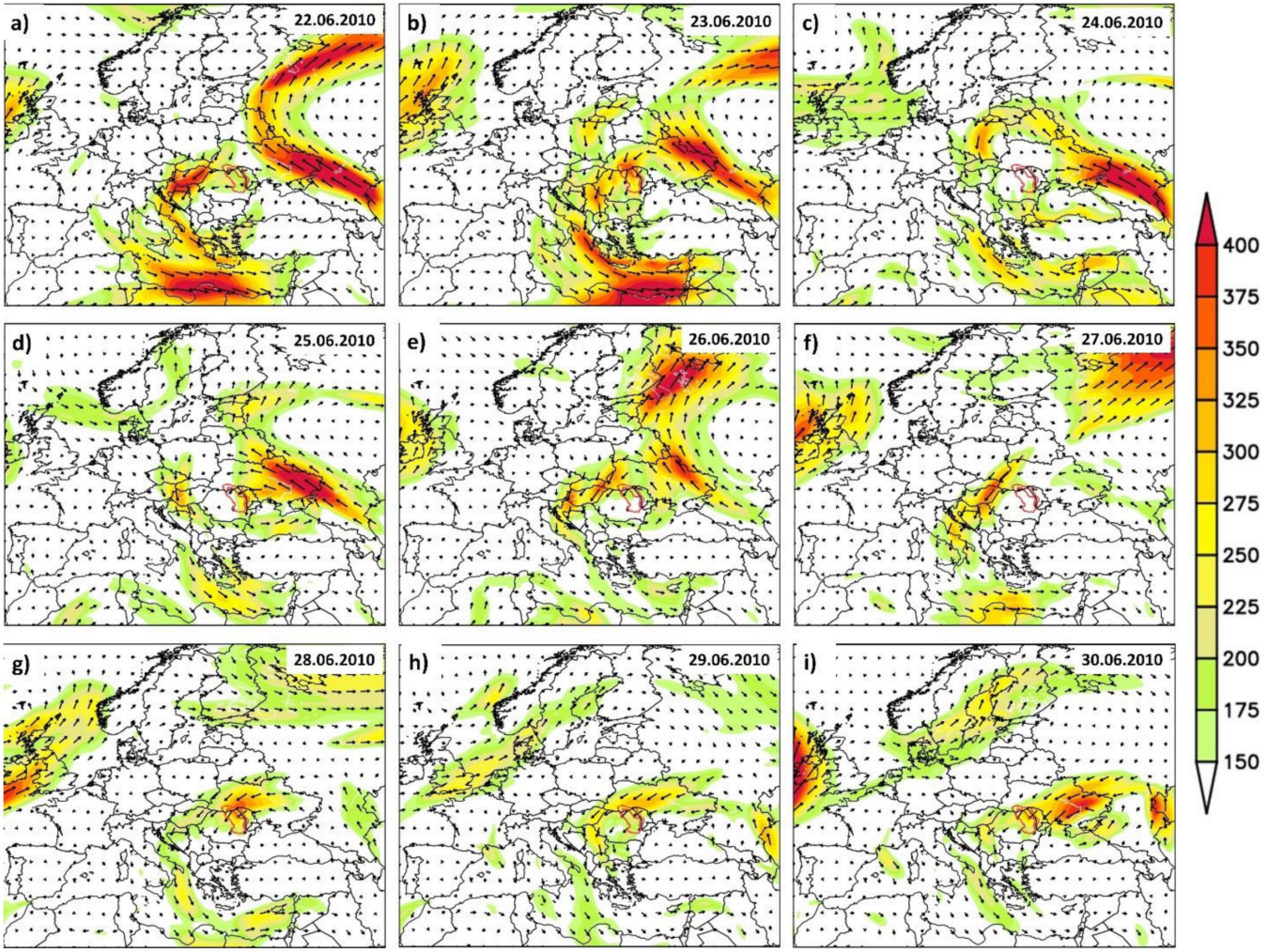

Figure 8. Magnitude (shaded colors) and direction (vectors) of the daily integrated water vapor transport (WVT) for: (a) 22 June 2010; (b) 23 June 2010; (c) 24 June 2010; (d) 25 June 2010; (e) 26 June 2010; (f) 27 June 2010; (g) 28 June 2010; (h) 29 June 2010; and (i) 30 June 2010. Units: WVT $\left(\mathrm{kg} \cdot \mathrm{s}^{-1} \cdot \mathrm{m}^{-1}\right)$.
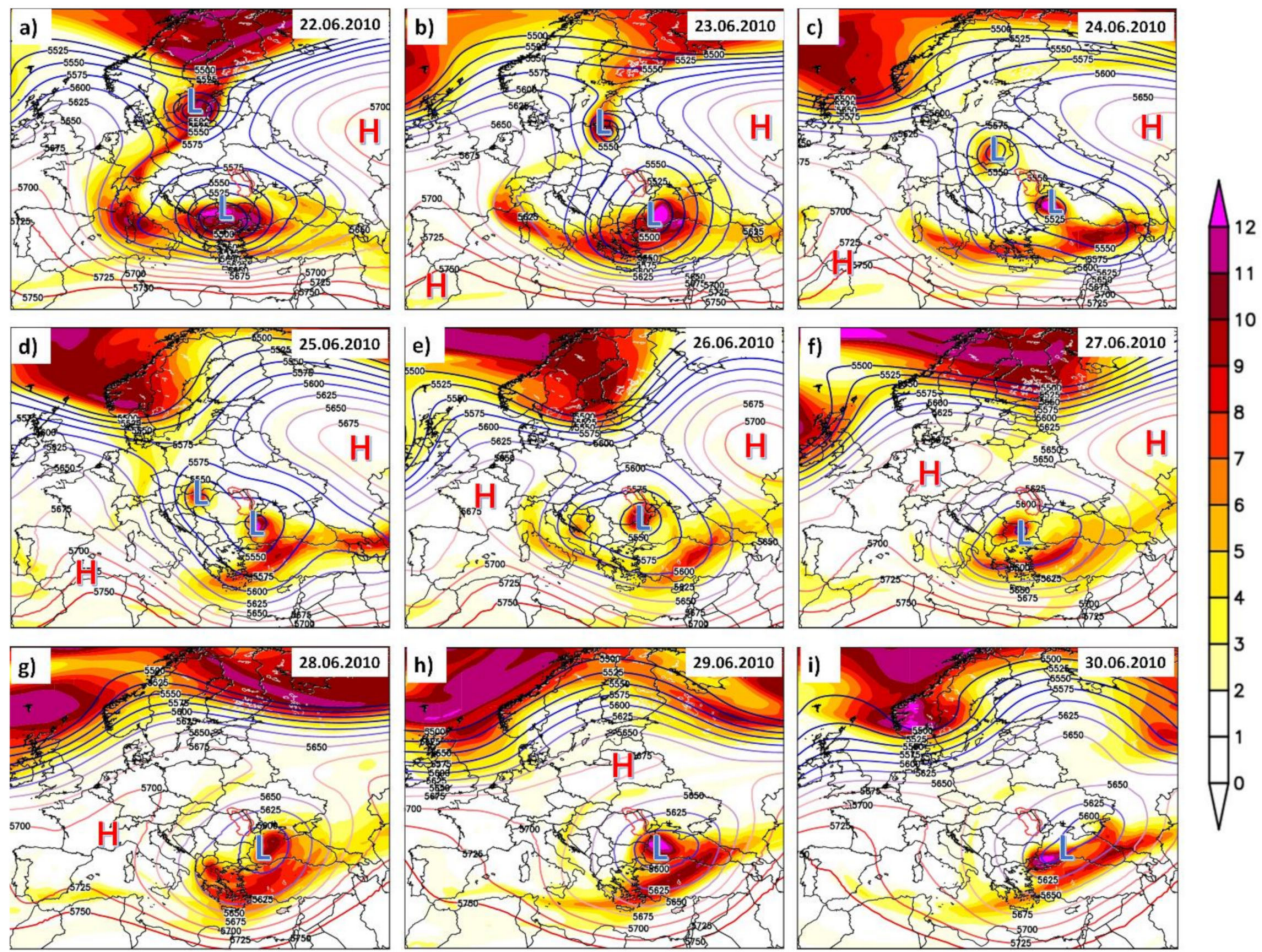

Figure 9. Daily potential vorticity (PV) at $330 \mathrm{~K}$ (shaded colors) and daily geopotential height at $500 \mathrm{hPa}$ (Z500) (contour lines) for: (a) 22 June 2010; (b) 23 June 2010; (c) 24 June 2010; (d) 25 June 2010; (e) 26 June 2010; (f) 27 June 2010; (g) 28 June 2010; (h) 29 June 2010; and (i) 30 June 2010. Units: PV (PVU) and Z500 (m). L (blue) denotes low-pressure systems and H (red) denotes high-pressure systems. 


\subsubsection{Socio-Economic Impact of June 2010 Flood Event}

The heavy rainfall events, in summer 2010, led to extreme flooding not only on the Siret and Prut River basin but also over central and eastern part of Europe, with a high impact on different social and economic sectors [49]. The financial impact of the 2010 flood in Romania was estimated at $\approx 1$ billion Euro [46], and 24 flood casualties were reported [50]. The flood has affected 426 localities in various degrees, more than 3936 households (out of which 863 were completely destroyed), $\approx 110,000$ ha agricultural land, 707 bridges and 2729 small bridges, $31 \mathrm{~km}$ of water supply, 147 social and economic objects (out of which 87 schools, 3 hospitals and 33 churches), and over $5200 \mathrm{~km}$ of national and regional roads, 14,000 wells. Moreover, more than 17,000 people were evacuated [50-54].

The economic losses caused by the catastrophic 2010 flood in the Republic of Moldova were estimated at $\approx 35.19$ million Euro. Among the reported casualties and damages, we have two flood victims, more than 13,000 affected people, and more than 4000 evacuated people; in total, 1105 households, 4308 ha of farmlands, 4800 ha of pastures, and 930 ha of forests were damaged [44,47,49]. In addition, the amplitude of the flood peaks and its duration led to the degradation and breaking of the dikes and the flooding of agricultural lands and some localities from Nisporeni, Hîncești, Leova, Cantemir, and Cahul. For example, the anti-flood dam from Nemneti broke on the 6th of July 2010, flooding more than 3800 ha, including Catul Morii, Obileni, and Sarateni localities. On the 13th of July, a controlled break of the dam from the confluence with the Nirnava river was performed in order to avoid a possible accidental break [45,48]. In Ukraine, the economic losses due to the June-July 2010 floods were evaluated at more than 1 million $€$, while 28 localities, more than 750 households, 12,000 ha of agricultural land, and numerous roads and infrastructure facilities were affected [50].

\subsection{June 2020 Flood Event \\ 3.3.1. Hydrological Situation}

The heavy rainfall events observed between 17th of June until 23rd of June 2020 caused catastrophic floods in the central and eastern part of Romania, including the Siret and Prut River basins (Figure 10). Over this period, an exceptional precipitation amount fell over the eastern part of Romania, the Republic of Moldova, and Ukraine (Figure 10). At Rădăuți meteorological station, a rainfall amount of $\approx 55 \mathrm{~mm} /$ day was recorded on the 22 nd of June, which is half of the monthly average (Figures S2c and S3c, Table S3). Overall, the precipitation falling over the western part of Ukraine and the Republic of Moldova in June 2020 was up to six times higher than the monthly average [55].

The 2020 flood in Siret and Prut River basins had different characteristics due to the different streamflow values, water volume, duration, affected area, and due to different socio-economic impact. The June 2020 flood wave on the Siret Rivers started as a result of high precipitation amounts in the upper part of the river's basin. At Lespezi hydrometric station (Siret River), the streamflow started to rise on the 15th of June 2020, when a daily streamflow more than double compared to the previous day $\left(105 \mathrm{~m}^{3} / \mathrm{s} \mathrm{vs.} 55 \mathrm{~m}^{3} / \mathrm{s}\right)$ was recorded. The streamflow stayed at an elevated, but there were stable levels until the 21st of June, after which it started to rise very fast, until the 24th of June, when a flood peak of $640 \mathrm{~m}^{3} / \mathrm{s}$ was recorded (Figure 11a,b). The flood wave propagated downstream of the Siret River.

Overall, the 2020 flood wave on the Siret River was much lower compared to those from 2008 and 2010. Opposite to this, on the Prut River, the 2020 flood wave was catastrophic, with streamflow values comparable with those from 2008 and 2010. On the Prut River, two flood peaks were recorded in June 2020, one of mean size and one of catastrophic amplitude (Figure 11c,d). The first flood wave at Rădăuți-Prut hydrometric station occurred between 14th and 21st of June 2020, with a doubling of the streamflow from the 13th to the 14th June (e.g., from $149 \mathrm{~m}^{3} / \mathrm{s}$ to $293 \mathrm{~m}^{3} / \mathrm{s}$ ). The upward trend of the flow was maintained until the 16th of June, when the peak of the first flood $\left(766 \mathrm{~m}^{3} / \mathrm{s}\right)$ was recorded, after which the streamflow began to decrease progressively until the 21st of June, when 
the streamflow recorded a value of $281 \mathrm{~m}^{3} / \mathrm{s}$ (Figure 11c,d). Due to the high precipitation amounts that fell over the upper part of the Prut basin between the 20th of June and the 25th of June 2020, the streamflow started to rise again and determined large-scale floods on the Prut River. At Chernovtsy hydrometric station (Ukraine), the streamflow started to rise on June 21 and reached the flood peak on June 24 , with $1490 \mathrm{~m}^{3} / \mathrm{s}$, after which the streamflow started to decrease slowly, recording a daily streamflow of $406 \mathrm{~m}^{3} / \mathrm{s}$ on the 27 th of June [55]. At Rădăuți-Prut hydrometric station, the second flood wave began on the 22nd of June, with a rapid, exponential increase of the streamflow, which reached the maximum flood peak $\left(2920 \mathrm{~m}^{3} / \mathrm{s}\right)$ four days later, on the 26th of June (Figure 11c,d). Exceptional high daily streamflow values were maintained until the 27th of June, after which the streamflow started to decrease rapidly, reaching relatively normal values $\left(265 \mathrm{~m}^{3} / \mathrm{s}\right)$ on the 30th of June 2020. The flood wave propagated downstream of Rădăuți-Prut hydrometric station with similar characteristics until the accumulation Stânca-Costești lake, which took over most of the volume of water coming from upstream. Nevertheless, in order to avoid exceeding the maximum level of the lake, the water from the lake was evacuated with a streamflow value of $\approx 590 \mathrm{~m}^{3} / \mathrm{s}$ until the 24 th of June, with $\approx 630 \mathrm{~m}^{3} / \mathrm{s}$ on the 25 th of June, and with $680 \mathrm{~m}^{3} / \mathrm{s}$ between the 26th and 27th of June 2020 [55]. Starting with the 27th of June, the decision was made to gradually decrease the water discharge streamflow from the lake, reaching a value of $180 \mathrm{~m}^{3} / \mathrm{s}$ on the 5th of July 2020 [55]. The increase of the streamflow up to six times higher than the average for this month led to record levels of the daily streamflow (Figure 11d) on the river Prut and caused the flooding of agricultural land and some localities downstream of the Stânca-Costești lake.

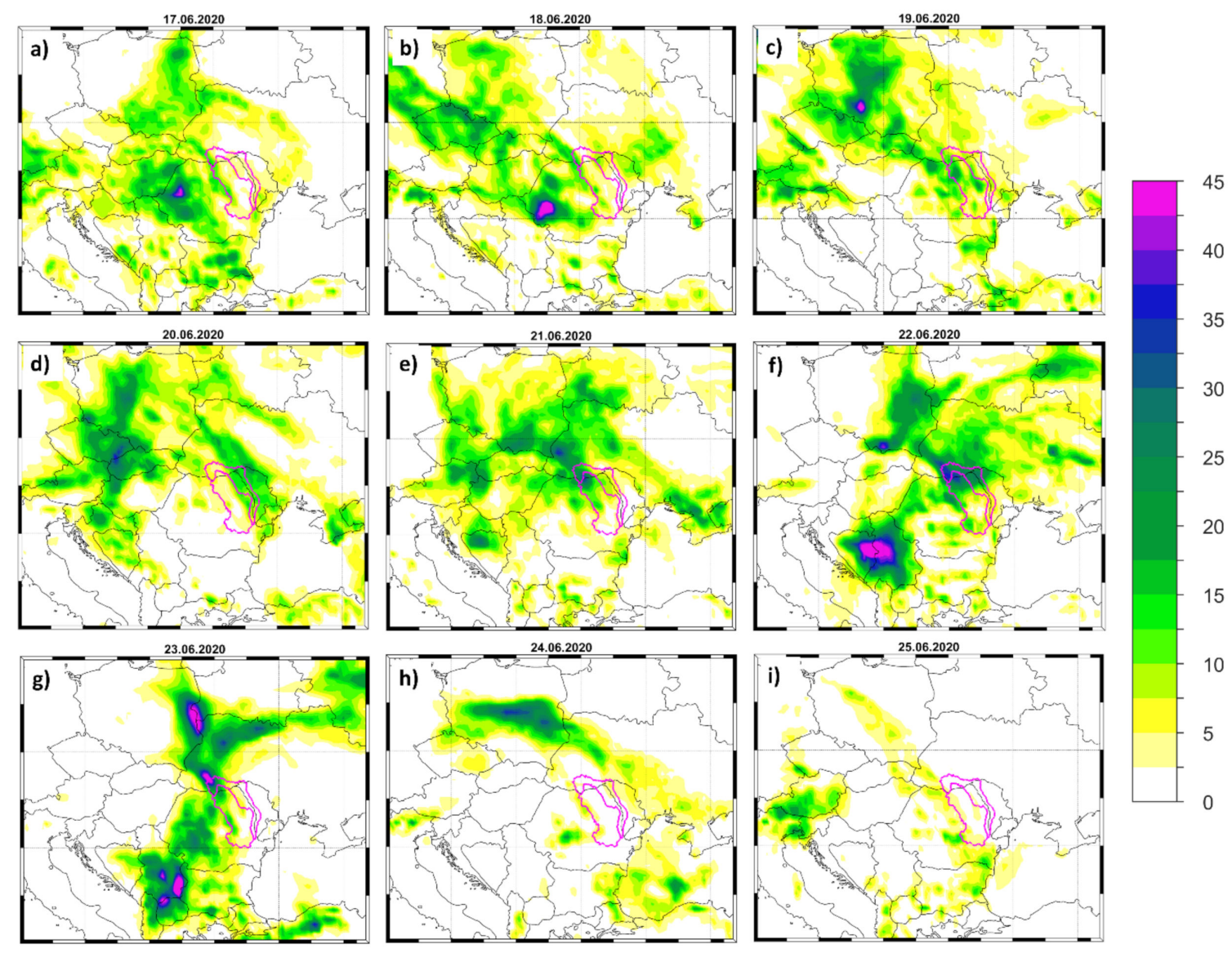

Figure 10. Daily precipitation totals (PP) for(a) 17 June 2020; (b) 18 June 2020; (c) 19 June 2020; (d) 20 June 2020; (e) 21 June 2020; (f) 22 June 2020; (g) 23 June 2020; (h) 24 June 2020 and (i) 25 June 2020. Units: PP (mm/day). 
(a)

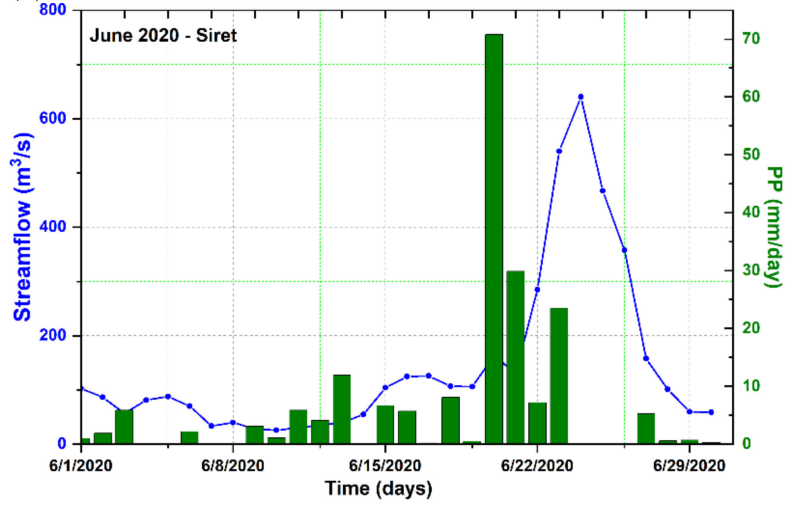

(c)

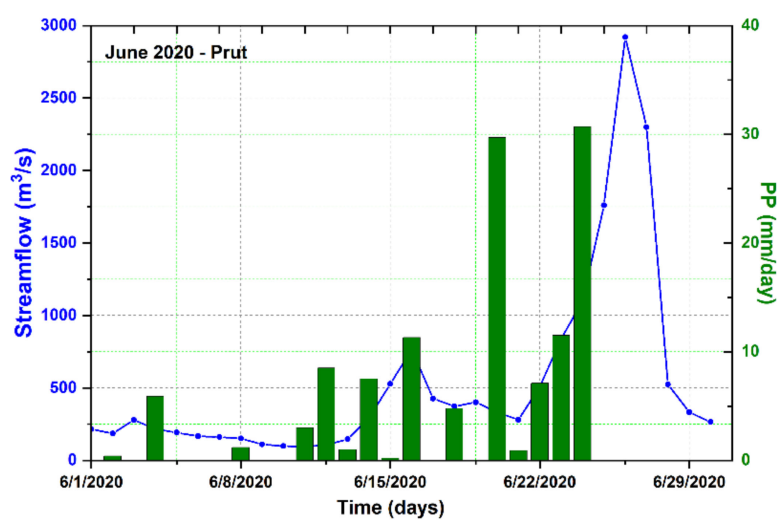

(b)

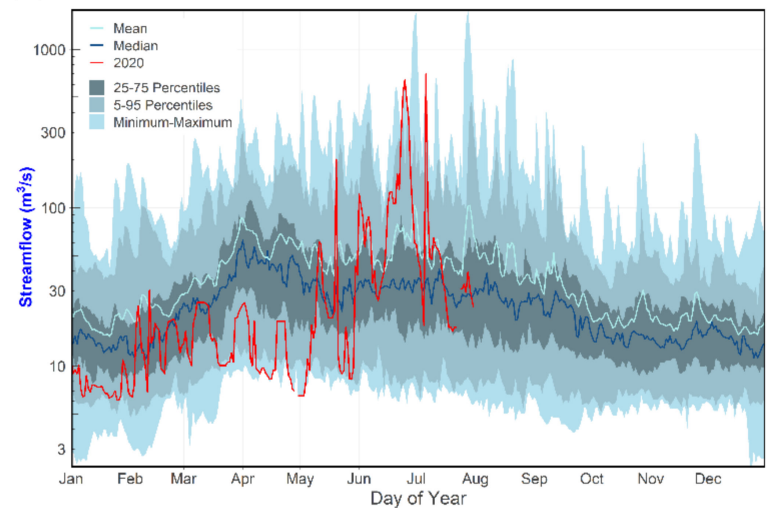

(d)

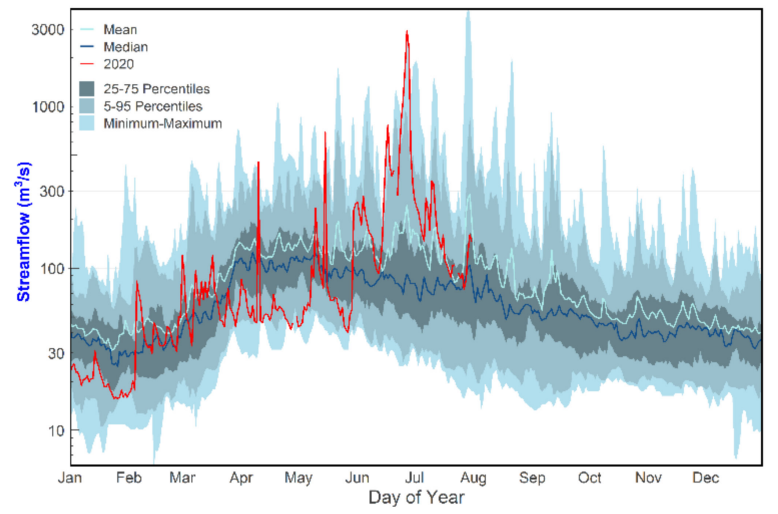

Figure 11. (a) Daily streamflow at Lespezi gauging station situated on the Siret River (blue line) and the precipitation amount at Rădăuți meteorological station (green bars) for the period 1 June-30 June 2020; (b) The evolution of the flood peak in June 2010 (red line) at Lespezi gauging station compared to the daily streamflow pattern on an annual basis (blue shaded line); (c) Daily streamflow at Rădăuți-Prut gauging station situated on the Prut River (blue line) and the daily precipitation amount at Darabani meteorological station (green bars) for the period 1 June-30 June 2020; (d) The evolution of the flood peak in June 2010 (red line) at Rădăuț-Prut gauging station compared to the daily streamflow pattern on an annual basis (blue shaded area). For the location of the gauging and meteorological stations, see Figure 1. The period 1981-2000 was used to compute the daily streamflow climatology in (b,d). For 2020 streamflow data was available just for the period 1 January 2020-31 July 2020.

\subsubsection{Atmospheric Conditions}

Between 17th and 24th of June 2020 were days with extreme precipitation events, which were associated with intense water vapor transport over Ukraine and the northern part of Romania (Figure 12). Between the 17th and 22nd of June, the axis of the water vapor transport was confined mainly over the northern part of Ukraine, where the highest rainfall amounts were recorded (Figure 12a-f). The heavy rainfall events in June 2020 were triggered, such as in the case of July 2008 and June 2020 events, by strong high PV anomalies extending from the North Atlantic basin toward the eastern part of Europe (Figure 13) and several low-pressure systems (Figure 13), which developed in cycles of two or three days. Opposite to the June 2010 event, the June 2020 event featured a diffluent blocking pattern (Figure 13), where a high-pressure center started to slide above a lowpressure center on the 21st of June 2020, reaching this northward center on the 24th of June 2020. The positive PV anomalies associated with the moving low-pressure system, and the structure of the geopotential height anomalies at the $500 \mathrm{hPa}$ allowed the advection of cold air from the north toward our analyzed region (Figure S6), leading to heavy rainfall events especially over Ukraine and the north-eastern part of Romania. As in the case of the June 2010 event, the low-pressure systems that reached the Black Sea basin were enriched with large amounts of water vapor afterwards (Figure 12) and moved toward the northeastern part of Romania, leading to heavy rainfall and flooding. Under the 
aforementioned synoptic conditions, the atmospheric instability over the eastern part of Europe led to stormy phenomena and rains with torrential character, the most affected areas being the north-eastern part of Romania, the Republic of Moldova, and Ukraine.
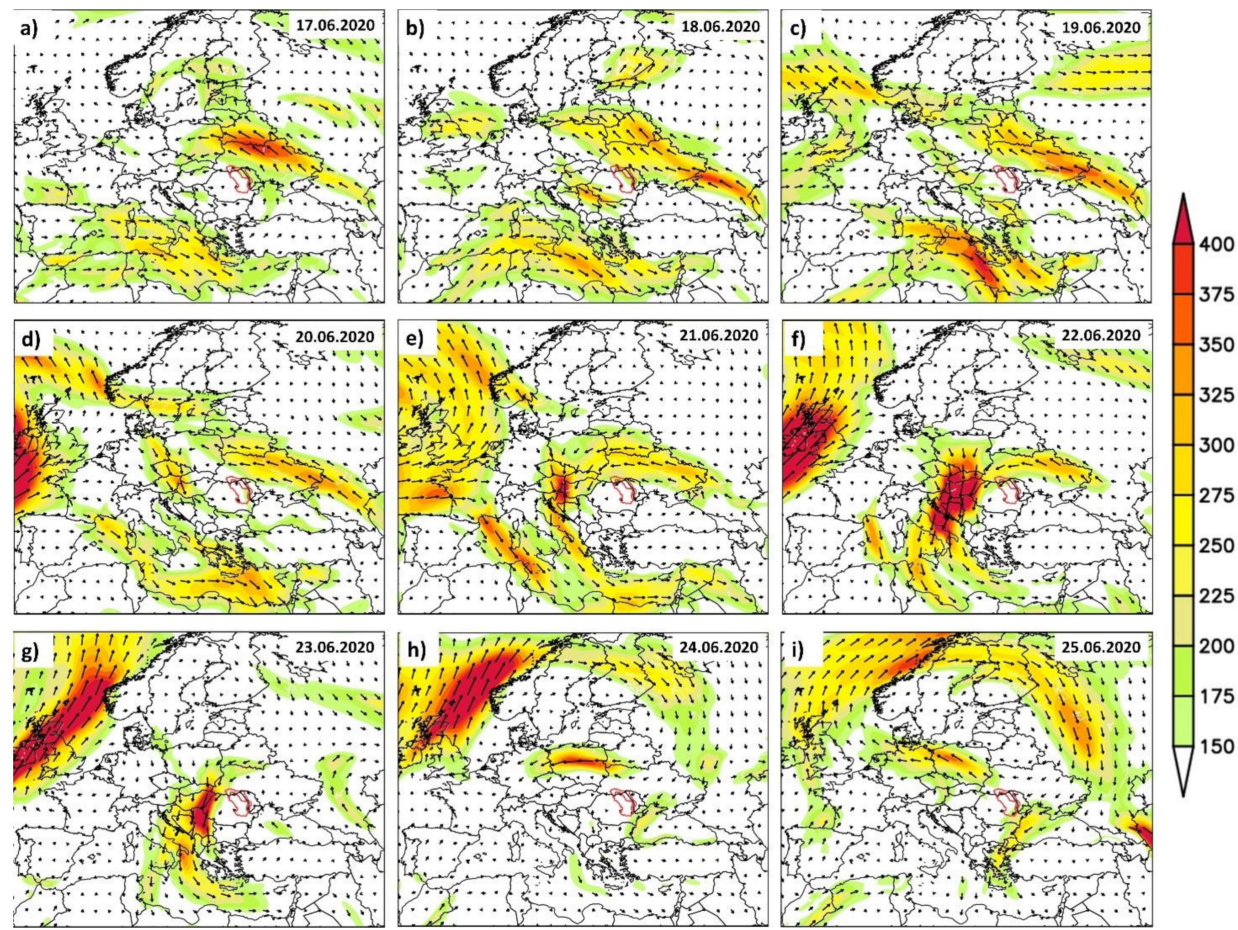

Figure 12. Magnitude (shaded colors) and direction (vectors) of the daily integrated water vapor transport (WVT) for: (a) 17 June 2020; (b) 18 June 2020; (c) 19 June 2020; (d) 20 June 2020; (e) 21 June 2020; (f) 22 June 2020; (g) 23 June 2020; (h) 24 June 2020 and (i) 25 June 2020. Units: WVT $\left(\mathrm{kg} \cdot \mathrm{s}^{-1} \cdot \mathrm{m}^{-1}\right)$.
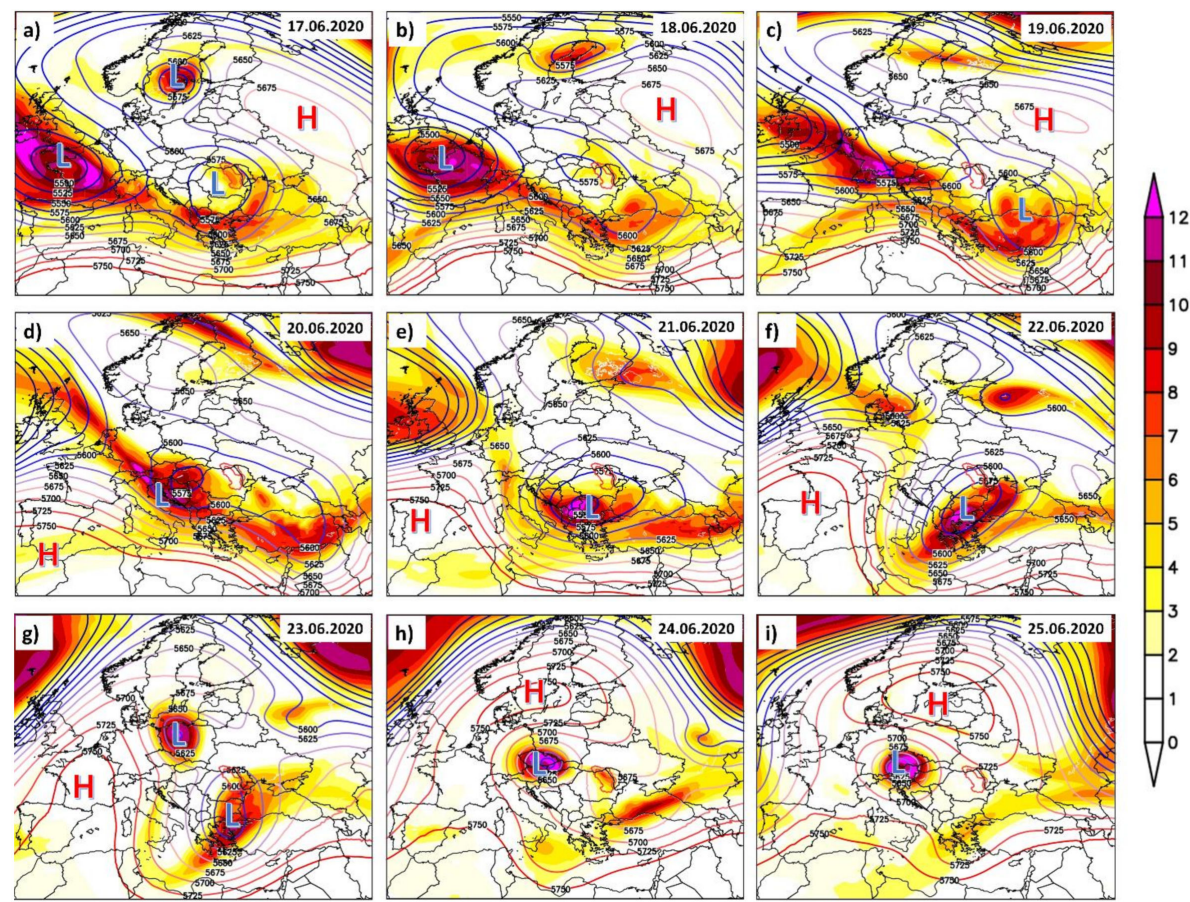

Figure 13. Daily potential vorticity (PV) at $330 \mathrm{~K}$ (shaded colors) and daily geopotential height at $500 \mathrm{hPa}$ (Z500) (contour lines) for: (a) 17 June 2020; (b) 18 June 2020; (c) 19 June 2020; (d) 20 June 2020; (e) 21 June 2020; (f) 22 June 2020; (g) 23 June 2020; (h) 24 June 2020 and (i) 25 June 2020. Units: PV (PVU) and Z500 (m). L (blue) denotes low pressure system and H (red) denotes high pressure systems. 


\subsubsection{Socio-Economic Impact of June 2020 Flood Event}

The extreme floods from June 2020 caused numerous socio-economic damages, not only on the Siret and Prut River basins but also in other rivers basins from the centraleastern part of Europe. In Romania, the government allocated $\approx 68$ million Euro in order to restore the affected areas by flood [56,57], but the total flood damage was estimated at $\approx 290$ million Euro (the floods affected 161 localities in 29 counties) [58,59]. In addition, in the summer of 2020 due to the floods in Romania, three casualties were reported [59,60]. In the Siret and Prut River basins, $\approx 300$ peoples were evacuated, and nearly 400 households and 600 courtyards were flooded, while many bridges and footbridges, several kilometers of national roads, railways (between Gura-Humorului and Frasin), county roads, and streets were damaged $[57,58,60]$.

In the Republic of Moldova, the most affected areas were on the sector from the entrance of the Prut River on the territory of the Republic of Moldova to the StâncaCostești accumulation lake, especially Edineț and Briceni, where dozens of households were evacuated, [58,61]. The total economic damages due to high water levels and heavy precipitation in the Prut River basin were estimated at more than 2 million Euro, of which $\approx 240,000$ Euro were economic costs in the Birceni region [62,63].

The 2020 flood had a high socio-economic impact also in Ukraine. The Ukrainian government allocated 25 million Euro immediately after the flood to eliminate the effects of floods in the western part of Ukraine [43], but the total damages were estimated at $\approx 90-120$ million Euro [64]. Three flood victims were recorded, while more than 11,000 households were flooded, $\approx 300$ people were evacuated, $\approx 90$ bridges were destroyed, and more than $400 \mathrm{~km}$ of national and local roads were damaged (including a highways section). The railway was damaged, and many trains were canceled on the route Ivano-Frankivsk-Vorokhta [43]. In Bucovina, several villages were left without gas supply, and in Chernivtsi, the Prut River overflowed its banks and flooded two big markets (Kalinovsky and Dobrobut), while the most difficult situation was in mountainous areas, where many villages and hamlets were left without road traffic due to landslides and destruction of the road surface [43]. A summary of the hydrometeorological pre-conditioning of each flood event, the flood damages, and the flood management policy are given in Table S4.

\section{Perspectives}

The increase in the frequency and intensity of recent floods is a consequence of multiple factors [65]. The extreme floods events from the recent period can be a consequence of global warming, due to an increase in the frequency of extreme precipitation events [66]. Future climate scenarios indicate that the projected changes in the 100-year river flood peak, for two level of global warming $\left(1.5^{\circ} \mathrm{C}\right.$ and $\left.3{ }^{\circ} \mathrm{C}\right)$ will increase in most of the European region, including the eastern part of the continent [2]. For Siret and Prut Rivers, an increase of up $20 \%$ in the 100 -year river flood peak is projected for the high-end $\left(3{ }^{\circ} \mathrm{C}\right)$ global warming scenario (Figure S7). In addition to climate change, anthropic activities through the intense deforestation of Carpathian forests especially after 1991 [47], and/or modification of the river flows played a significant role in the changing current hydrometric regime of the Siret and Prut Rivers. In addition to these causes, the water and flood management plans can contribute to a significant reduction of the flood impact. With the implementation of the European Flood Management Directive in Romania, in 2009 (and periodically updated), norms and procedures in the national legislation were transposed, which led to the implementation of some measurements to improve the flood risk management $[67,68]$. Recently, Ukraine and the Republic of Moldova started the work to implement also the European Directive for Flood Management in a national framework [69]. The Flood Risk Management Plan (FRMP) includes a wide combination of measures and actions taken: (i) improvement of the early warning system in order to inform the about flood risks; (ii) improving the preparedness for floods events and flood protection infrastructure; (iii) establishing procedures for operational activities during the floods; and (iv) post-flood adaptation measures for the full recovery of damages caused by 
flood and adaptation of the flood management plan according to last flood experience [70]. In addition, mitigating the flood effects requires a good coordination of the management plans between the countries on which the river basins are located. In the case of Siret and Prut Rivers, a proper coordination between Romania, Ukraine, and the Republic of Moldova is required, measurements which are also included in the FRMP. These measures will allow the evacuation of water in time from the accumulation lakes, which will permit flood wave attenuation. Overall, the implementation of the European Food Management Directive in Romania has already led to an improvement of regional flood management compared with the other two countries, the information system on flood risk alert being improved (e.g., implementation of RO-alert in 2018, issuing warning codes, and flood danger), as well as the application of preventive measures (e.g., evacuation of the people from the risk area). Romania (together with the Republic of Moldova on the side of the Prut River) is also benefiting from large infrastructure projects (e.g., dams, accumulation lakes) built in the past that have a crucial role in flood management. On the other hand, underfunding of flood defense infrastructure projects in Ukraine represent a major problem with long-term negative impact [71]. In this respect, the advantages of the implementation of the Flood Management Plan in Romania were observed during the 2020 flood event compared with the other flood events (e.g., 2008 and 2010). In the case of the 2020 flood event, the authorities took several precautionary measurements that mitigated the impact of the flood: a good flood forecast permitted water evacuation from the Stânca-Costești accumulation lake weeks before the occurrence flood event, so it can diminish the flood peak; multiple warning codes for flood risk were issued, and the population from the risk areas was alerted via the RO-alert program ( 55 alerts). Moreover, portions of the Prut River bank were consolidated with sandbags $(20,000)$ and mobile panels (500 linear meters), in order to protect the population living in the floodplain of the Prut River (Oroftiana, Baranca and Rădăuți-Prut localities) [58]. Thus, the implementation of the European Flood Management Plan in accordance with climate change scenarios together with investments in the flood infrastructure and high-resolution streamflow forecast remain the key solution to mitigate flood effects and reduce the negative impact of floods in a long-term perspective.

\section{Discussion and Conclusions}

Floods are among the most damaging natural hazards at the European level, and despite improved early warning systems and better flood control infrastructure, flood damage has grown considerably, as the flood-vulnerable areas have gained richer infrastructure and wealth [65,72]. Overall, Europe's capability to prepare for such disasters, such as floods and/or droughts, is challenged by a large range of uncertainties and a limited understanding of the driving forces of hydrometeorological hazards [73]. Extreme floods are often caused by heavy rainfall events that are strongly influenced by synoptic to mesoscale conditions [38,74-77]. Numerous researchers have investigated the meteorological conditions behind major flood events at the European level and modeled climate-flood relationships [78,79]. Typical approaches for analyzing the relationship between large-scale atmospheric circulation and floods include correlation, regression, and composite analysis. In general, correlation and linear regression are used to analyze a single or few atmospheric variables, whereas composites are used to explore gridded atmospheric fields $[12,78,79]$. In their study, Prudhomme and Genevier (2011) [80] investigated the relationship between circulation types and flood across Europe, and they showed that hydroclimatological connections are more spatially coherent in winter than summer, while Jacobeit et al. (2006) [81] found that flooding in central Europe is preceded by particular cyclone tracks, and these cyclone tracks differ seasonally and between regions. Looking from a long-term perspective, Mudelsee et al. (2004) [82] found that severe floods in central Europe over the last 500 years are associated with the $\mathrm{Vb}$-cyclone track. Rimbu et al. (2021) [25] have shown that summer floods in the southern part of Germany are triggered by heavy rainfall events corroborated with an increase in the frequency of upper-level potential vorticity events over the western part of Europe. Overall, it has been shown that the climatic drivers of European floods 
may differ between season and region, and the severity of the analyzed flood events. All aforementioned studies and the references therein, which dealt with analyzing the linkages between floods and large-scale atmospheric circulation patters, at European level, were focused on the western and central part of Europe, but no such detailed analyses exist for the eastern part of Europe. Thus, in the current study, we analyzed the linkages between extreme floods in two of the largest catchment areas in Romania (Siret and Prut Rivers) and their large-scale atmospheric circulation drivers, in order to fill the gap, at least partially, regarding such studies in the eastern part of Europe.

In this study, we have shown that extreme floods in the eastern part of Europe occur predominantly in summer, after heavy rainfall episodes associated with pivotal low-pressure systems and high potential vorticity anomalies, which corroborated with intense moisture transport from the Mediterranean Sea and Black Sea toward Romania, Ukraine, and Moldova. This study was motivated by the fact that no comparative studies are available over the eastern part of Europe that consider all the features of extreme flood events: hydrological characterization of the flood peaks, an in-depth analysis of the largescale atmospheric drivers, and a detailed analysis and overview of the associated impacts onto the society and economy of these extreme flood events. Due to their geographical position and special climate feature, the Siret and Prut Rivers are periodically affected by floods, the floods from 2008, 2010, and 2020 being among the largest floods recorded over this region during the last 80 years, in terms of flood parameters and their impact. In addition to their destructive effect and magnitude, these three floods also have in common the climatic preconditions that led to the formation of flood waves: a high amount of precipitation was recorded over the Ukrainian Carpathian regions, where the upper part of the Siret and Prut basins are situated. In general, floods are difficult to forecast, especially in the case of rivers basins situated in the near vicinity of complex topography $[38,83]$. The results presented here indicate that extreme flood events may be recognized in advance thanks to their large-scale precursors (e.g., WVT, PV intrusions, and cut-off lows). All three flood events were preceded by exceptionally heavy rains, which fell during a short period (of the order of the days), leading to record rainfall quantities that exceed the monthly norm, reaching even a double or higher amount. The large amounts of precipitation that fell in a record time led to the rapid increase of the streamflow, both on the main tributaries and the main rivers, which led to a propagation of the flood wave. All three extreme flood events were triggered by similar large-scale atmospheric features: high PV anomalies over the analyzed regions, persistent cut-off lows, and increased water vapor transport over the catchment area of the two rivers, which led to heavy rainfall events and as a consequence to catastrophic floods.

The shape of the PV anomalies for all our analyzed cases indicate the presence of an anticyclonic Rossby wave breaking [84]. The days prior to the flood peaks, for all analyzed events, are associated with an anticyclonic Rossby wave breaking and intense water vapor transport (ARWB, Table 2), which is in agreement with previous studies $[8,25]$ that have shown that extreme flood events over Europe are linked mostly with ARWBs. From a synoptic point of view, the flood events in this study were preceded by very particular weather regimes [85]. In July 2008, there were three particular weather regimes prevailing the days prior to the flood peak: WZ (West cyclonic), TRM (trough over central Europe), and HNFZ (High Pressure over Fennoscandia). In June 2010 and July 2020, one of the preferred weather regimes prior to the flood peaks was the BM (High Pressure over Central Europe), which is characterized by an anticyclonic bridge over central Europe. Under the prevailing large-scale synoptic conditions associated with BM and HNFZ, the eastern part of Europe, especially Romania, resides at the south of the high-pressure system, in an area of low air pressure where the air circulation is cyclonic and where the influence of either Mediterranean Sea, or the Black Sea, is poignant. The influence of the Black Sea on the intensity of the rainfall events and the flood peaks is very well captured by the direction of the WVT for all analyzed cases. Overall, all three flood events took place either when there has been a low-pressure system in the immediate vicinity of the country, especially in the 
southern part, or when the pressure field was generally weak. In addition, the blocking situations are an essential ingredient for flood occurrence over our analyzed area, because they lead to the persistence of advection of warm and humid air from the Black Sea or the Mediterranean Sea.

Table 2. Days with anticyclonic Rossby wave breaking (ARWB) and the type of circulation patterns (Großwetterlage-GWL) active during the days prior to the flood peaks in July 2008, June 2010 and June 2020. "*”-indicates the days when ARWB occurred.

\begin{tabular}{ccccccccc}
\hline & 2008 & & & 2010 & & & 2020 & \\
\hline Day & ARWB & GWL & Day & ARWB & GWL & Day & ARWB & GWL \\
\hline 19.07 & & WZ & 22.06 & $*$ & HM & 17.06 & & SEZ \\
20.07 & & WZ & 23.06 & $*$ & HM & 18.06 & HNFZ \\
21.07 & & TRM & 24.06 & & HM & 19.06 & HNFZ \\
22.07 & & TRM & 25.06 & & BM & 20.06 & & HNFZ \\
23.07 & $*$ & TRM & 26.06 & & BM & 21.06 & $*$ & BM \\
24.07 & $*$ & HNFZ & 27.06 & $*$ & BM & 22.06 & $*$ & BM \\
25.07 & $*$ & HNFZ & 28.06 & $*$ & BM & 23.06 & $*$ & BM \\
26.07 & $*$ & HNFZ & 29.06 & $*$ & BM & 24.06 & $*$ & SEA \\
27.07 & $*$ & HNFZ & 30.06 & $*$ & BM & 25.06 & $*$ & SEA \\
\hline
\end{tabular}

Overall, the main conclusions of this study can be summarized as follows:

- In terms of the streamflow amplitude and impact, the flood from July 2008 was the highest since instrumental data became available. In 2008, the streamflow reached values up to $2414 \mathrm{~m}^{3}$ / s on the Siret River and up to $4033 \mathrm{~m}^{3} / \mathrm{s}$ on the Prut River, while the total economic damages were more than 2 billion Euro.

- $\quad$ During the flood from June to July 2010, the recorded streamflow was lower compared to $2008\left(1678 \mathrm{~m}^{3} / \mathrm{s}\right.$ and $1930 \mathrm{~m}^{3} / \mathrm{s}$ on Siret and Prut Rivers respectively), while the total damage was estimated at more than 1 billion Euro.

- The flood from June 2020 had particular characteristics, with extraordinary high streamflow on the Prut River (the second biggest flood after July 2008 flood), which reached up to $2920 \mathrm{~m}^{3} / \mathrm{s}$, while on the Siret River, the highest streamflow was $640 \mathrm{~m}^{3} / \mathrm{s}$ recorded on June 24. The total damages of the June 2020 flood event were estimated at approximately half a billion Euro (Table 1 and S4).

- The Prut streamflow exceeded 33 times the monthly norm during the 2008 flood, 24 times during the 2020 flood, and 16 times during the 2010 flood, while for the Siret River, the streamflow exceeded 40 times the monthly norm during the 2008 flood, 28 times during the 2010 flood, and 10 times during 2020 flood.

- All flood events analyzed in this study were triggered by similar large-scale atmospheric features: PV intrusions associated with Rossby wave breaking, cold air advection from the north toward our analyzed region (e.g., Siret and Prut River basins), pivoting cut-off lows, and increased water vapor transport over the catchment area of the two rivers.

- The time lag between the peak of the WVT and the flood peak ( $\approx 3-4$ days) can be used as a potential predictor for the upcoming floods. The moisture advection from the Mediterranean Sea and the Black Sea led to repeated episodes of heavy precipitation over a few days, which in turn triggered record-breaking flood peaks.

- Atmospheric blocking, albeit its frequent association with droughts and heat waves, is one of the leading triggers for large-scale condition favoring the atmospheric instability over the eastern part of Europe and rains with torrential character.

This study adds a new understanding of the physical processes leading to the occurrence of heavy rainfall events and extreme flooding in the eastern part of Europe, which could help to a better predictability and impact assessment of future flood events, especially since the topic of predictability becomes essential in the view of an increase in the likelihood of extreme flooding in a warming climate. 
Supplementary Materials: The following are available online at https://www.mdpi.com/article/10 .3390/w13081122/s1. Figure S1: (a) Time series of the daily streamflow at Lespezi gauging station (Siret River) and b) Time series of the daily streamflow at Rădăuț-Prut gauging station (Prut River). Analyzed period: 1 January 1978-31 December 2008. The horizontal lines indicated the flow peak for the flood events of July 2008 (red line), June 2010 (magenta line) and June 2020 (green line). The magnitude of the flood peaks for these events is given in Table 2. Figure S2. The evolution of the daily precipitation at Rădăuți-Prut meteorological station for (a) July 2008 (red line) compared to the daily precipitation pattern on an annual basis (blue shaded area); (b) as in (a) but for June 2010 and (c) as in (a) but for June 2020. Figure S3. The evolution of the daily precipitation at Darabani meteorological station for (a) July 2008 (red line) compared to the daily precipitation pattern on an annual basis (blue shaded area); b) as in a) but for June 2010 and (c) as in (a) but for June 2020. Figure S4. Daily temperature at $850 \mathrm{hPa}$ (TT850) (shaded colors) and daily geopotential height at $850 \mathrm{hPa}$ (Z850) (contour lines) for: (a) 19 July 2008; (b) 20 July 2008; (c) 21 July 2008; (d) 22 July 2008; (e) 23 July 2008; (f) 24 July 2008; (g) 25 July 2008; (h) 26 July 2008 and (i) 27 July 2008. Units: TT850 ( ${ }^{\circ} \mathrm{C}$ ) and Z500 (m). Figure S5. Daily temperature at $850 \mathrm{hPa}$ (TT850) (shaded colors) and daily geopotential height at $850 \mathrm{hPa}$ (Z850) (contour lines) for: (a) 22 June 2010; (b) 23 June 2010; (c) 24 June.2010; (d) 25 June 2010; (e) 26 June 2010; (f) 27 June 2010; (g) 28 June 2010; (h) 29 June 2010 and (i) 30 June 2010. Units: TT850 $\left({ }^{\circ} \mathrm{C}\right)$ and Z500 (m). Figure S6. Daily temperature at $850 \mathrm{hPa}$ (TT850) (shaded colors) and daily geopotential height at $850 \mathrm{hPa}$ (Z850) (contour lines) for: (a) 17 June 2020; b) 18 June 2020; (c) 19 June 2020; (d) 20 June 2020; (e) 21 June 2020; (f) 22 June 2020; (g) 23 June 2020; (h) 24 June 2020 and (i) 25 June 2020. Units: TT850 ( $\left.{ }^{\circ} \mathrm{C}\right)$ and Z500 (m). Figure S7. Projected changes in the maximum 100-year daily river discharge for two global warming levels: (a) $1.5^{\circ} \mathrm{C}$ and (b) $3{ }^{\circ} \mathrm{C}$. The projections were downloaded from the Joint Research center website https: / / ec.europa.eu/jrc/en (accessed on 15 December 2020). Table S1. Daily precipitation totals recorded over the period 1 July-31 July2008 at different meteorological stations situated in the catchment area of Siret and Prut Rivers. Table S2. Daily precipitation totals recorded over the period 1 June-30 June 2010 at different meteorological stations situated in the catchment area of Siret and Prut Rivers. Table S3. Daily precipitation totals recorded over the period 1 June-30 June 2020 at different meteorological stations situated in the catchment area of Siret and Prut Rivers. Table S4. Hydrometeorological situation, socio-economic impact and management policy for the three extreme flood events analyzed in this study: July 2008, June 2010 and June 2020.

Author Contributions: M.I. and V.N. designed the study and wrote the paper. Both authors had equal contribution. Both authors have read and agreed to the published version of the manuscript.

Funding: M.I. was supported by Helmholtz Association through the joint program "Changing Earth-Sustaining our Future" (PoF IV) program of the AWI. Funding by the AWI Strategy Fund Project-PalEX and by the Helmholtz Climate Initiative-REKLIM is gratefully acknowledged. V.N. was supported partially by the project number PN-III-P1-1.1-PD-2019-0469.

Institutional Review Board Statement: Not applicable.

Informed Consent Statement: Not applicable.

Data Availability Statement: The data that support the findings of this study are openly available. The relevant papers associated with these datasets are referred in the text.

Acknowledgments: We acknowledge the use of all data sets cited in this paper and would also like to thank all the authors for making them free for scientific research.

Conflicts of Interest: The authors declare no conflict of interest. The funders had no role in the design of the study; in the collection, analyses, or interpretation of data; in the writing of the manuscript, or in the decision to publish the results.

\section{References}

1. UNISDR. The Human Cost of Weather-Related Disasters 1995-2015. Available online: https://reliefweb.int/sites/reliefweb.int/ files/resources/COP21_WeatherDisastersReport_2015_FINAL.pdf (accessed on 22 February 2021).

2. Alfieri, L.; Bisselink, B.; Dottori, F.; Naumann, G.; de Roo, A.; Salamon, P.; Wyser, K.; Feyen, L. Global projections of river flood risk in a warmer world. Earth Future 2017, 5, 171-182. [CrossRef]

3. WHO. Flooding: Managing Health Risks in the WHO European Region; World Health Organisation Regional Office for Europe: Copenhagen, Denmark, 2017; ISBN 978-9-28905-279-5. 
4. WHO. Floods in the WHO European Region: Health Effects and Their Prevention; Menne, B., Murray, V., Eds.; World Health Organisation: Geneva, Switzerland, 2013; ISBN 978-92-890-0011-6.

5. Chbab, E.H. How extreme were the 1995 flood waves on the rivers Rhine and Meuse? Phys. Chem. Earth 1995, 20, 455-458. [CrossRef]

6. Fink, A.; Ulbrich, U.; Engel, H. Aspects of the January 1995 flood in Germany. Weather 1996, 51, 34-39. [CrossRef]

7. Engel, H.; Busch, N.; Wilke, K.; Krahe, P.; Mendel, H.-G.; Giebel, H.; Zieger, C. Das Hochwasser 1993/94 im Rheingebiet; Bundesanstalt für Gewässerkunde, BfG-Nr.: Koblenz, Germany, 1994.

8. Ionita, M.; Nagavciuc, V.; Guan, B. Rivers in the sky, flooding on the ground: The role of atmospheric rivers in inland flooding in central Europe. Hydrol. Earth Syst. Sci. 2020, 24, 5125-5147. [CrossRef]

9. Ulbrich, U.; Brücher, T.; Fink, A.H.; Leckebusch, G.C.; Krüger, A.; Pinto, J.G. The central European floods of August 2002: Part 2 -Synoptic causes and considerations with respect to climatic change. Weather 2003, 58, 434-442. [CrossRef]

10. Ulbrich, U.; Brücher, T.; Fink, A.H.; Leckebusch, G.C.; Krüger, A.; Pinto, J.G. The central European floods of August 2002: Part 1-Rainfall periods and flood development. Weather 2003, 58. [CrossRef]

11. Ionita, M.; Dima, M.; Lohmann, G.; Scholz, P.; Rimbu, N. Predicting the June 2013 European Flooding Based on Precipitation, Soil Moisture, and Sea Level Pressure. J. Hydrometeorol. 2014, 16, 598-614. [CrossRef]

12. Ionita, M. Interannual summer streamflow variability over Romania and its connection to large-scale atmospheric circulation. Int. J. Climatol. 2015, 35, 4186-4196. [CrossRef]

13. Barredo, J.I. Normalised flood losses in Europe: 1970-2006. Nat. Hazards Earth Syst. Sci. 2009, 9, 97-104. [CrossRef]

14. Barredo, J.I. Major flood disasters in Europe: 1950-2005. Nat. Hazards 2007, 42, 125-148. [CrossRef]

15. Bissolli, P.; Friedrich, K.; Rapp, J.; Ziese, M. Flooding in eastern central Europe in May 2010—Reasons, evolution and climatological assessment. Weather 2011, 66, 147-153. [CrossRef]

16. Kelman, I. The autumn 2000 floods in England and flood management. Weather 2001, 56, 346-360. [CrossRef]

17. Posthumus, H.; Morris, J.; Hess, T.M.; Neville, D.; Phillips, E.; Baylis, A. Impacts of the summer 2007 floods on agriculture in England. J. Flood Risk Manag. 2009, 2, 182-189. [CrossRef]

18. Muchan, K.; Lewis, M.; Hannaford, J.; Parry, S. The winter storms of 2013/2014 in the UK: Hydrological responses and impacts. Weather 2015, 70, 55-61. [CrossRef]

19. Stevens, A.J.; Clarke, D.; Nicholls, R.J. Trends in reported flooding in the UK: 1884-2013. Hydrol. Sci. J. 2016, 61, 50-63. [CrossRef]

20. RPA. Study on Economic and Social Benefits of Environmental Protection and Resource Efficiency Related to the European Semester; J834/EU Semester; Risk \& Policy Analysts Ltd.: Norwich, UK, 2014.

21. Lavers, D.A.; Pappenberger, F.; Zsoter, E. Extending medium-range predictability of extreme hydrological events in Europe. Nat. Commun. 2014, 5. [CrossRef]

22. DeFlorio, M.J.; Waliser, D.E.; Guan, B.; Ralph, F.M.; Vitart, F. Global evaluation of atmospheric river subseasonal prediction skill. Clim. Dyn. 2019, 52, 3039-3060. [CrossRef]

23. Rimbu, N.; Dima, M.; Lohmann, G.; Musat, I. Seasonal prediction of Danube flow variability based on stable teleconnection with sea surface temperature. Geophys. Res. Lett. 2005, 32. [CrossRef]

24. Ionita, M.; Scholz, P.; Chelcea, S. Spatio-temporal variability of dryness/wetness in the Danube River Basin. Hydrol. Process. 2015, 29, 4483-4497. [CrossRef]

25. Rimbu, N.; Lohmann, G.; Ionita, M.; Czymzik, M.; Brauer, A. Interannual to millennial-scale variability of River Ammer floods and its relationship with solar forcing. Int. J. Climatol. 2021, 41, E644-E655. [CrossRef]

26. Hu, H.; Dominguez, F.; Wang, Z.; Lavers, D.A.; Zhang, G.; Ralph, F.M. Linking Atmospheric River Hydrological Impacts on the U.S. West Coast to Rossby Wave Breaking. J. Clim. 2017, 30, 3381-3399. [CrossRef]

27. Paltan, H.; Waliser, D.; Lim, W.H.; Guan, B.; Yamazaki, D.; Pant, R.; Dadson, S. Global Floods and Water Availability Driven by Atmospheric Rivers. Geophys. Res. Lett. 2017, 44, 310-387, 395. [CrossRef]

28. Guan, B.; Molotch, N.P.; Waliser, D.E.; Fetzer, E.J.; Neiman, P.J. The 2010/2011 snow season in California's Sierra Nevada: Role of atmospheric rivers and modes of large-scale variability. Water Resour. Res. 2013, 49, 6731-6743. [CrossRef]

29. Kreibich, H.; Blauhut, V.; Aerts, J.C.J.H.; Bouwer, L.M.; Van Lanen, H.A.J.; Mejia, A.; Mens, M.; Van Loon, A.F. How to improve attribution of changes in drought and flood impacts. Hydrol. Sci. J. 2019, 64, 1-18. [CrossRef]

30. Sommerwerk, N.; Hein, T.; Schneider-Jacoby, M.; Baumgartner, C.; Ostojić, A.; Siber, R.; Bloesch, J.; Paunović, M.; Tockner, K. Chapter 3-The Danube River Basin. In Rivers of Europe; Tockner, K., Uehlinger, U., Robinson, C.T., Eds.; Academic Press: London, UK, 2009; pp. 59-112; ISBN 978-0-12-369449-2.

31. Briciu, A.-E.; Mihăilă, D.; Lazurca, L.G.; Costan, L.-A.; Nagavciuc, V.; Bădăluță, C.-A. Observations on the spatial variability of the Prut River discharges. ANALELE Univ. Ştefan Mare Suceava Ser. Geogr. 2011, 20, 45-56. [CrossRef]

32. Cornes, R.C.; Schrier, G.; Van Der Besselaar, E.J.M.; Van Den Jones, P.D. An Ensemble Version of the E-OBS Temperature and Precipitation Datasets. Geophys. Res. Atom 2018, 123. [CrossRef]

33. Hersbach, H.; Bell, B.; Berrisford, P.; Hirahara, S.; Horányi, A.; Muñoz-Sabater, J.; Nicolas, J.; Peubey, C.; Radu, R.; Schepers, D.; et al. The ERA5 global reanalysis. Q. J. R. Meteorol. Soc. 2020, 146, 1999-2049. [CrossRef]

34. Peixoto, J.P.; Oort, A.H. Physics of Climate; Springer: New York, NY, USA, 1992. 
35. Romanescu, G.; Stoleriu, C.; Romanescu, A.M. Water reservoirs and the risk of accidental flood occurrence. Case study: StancaCostesti reservoir and the historical floods of the Prut river in the period July-August 2008, Romania. Hydrol. Process. 2011, 25, 2056-2070. [CrossRef]

36. Romanescu, G.; Stoleriu, C. Causes and effects of the catastrophic flooding on the Siret River (Romania) in July-August. Nat. Hazards 2013, 69, 1351-1367. [CrossRef]

37. Cazac, V.; Boian, I. Inundatiile Catastrofale din Vara Anului 2008 în Republica Moldova. Available online: http://old.meteo.md/ newsait/floods/floods1.htm (accessed on 17 December 2020).

38. Piaget, N.; Froidevaux, P.; Giannakaki, P.; Gierth, F.; Martius, O.; Riemer, M.; Wolf, G.; Grams, C.M. Dynamics of a local Alpine flooding event in October 2011: Moisture source and large-scale circulation. Q. J. R. Meteorol. Soc. 2015, 141, 1922-1937. [CrossRef]

39. Schlemmer, L.; Martius, O.; Sprenger, M.; Schwierz, C.; Twitchett, A. Disentangling the Forcing Mechanisms of a Heavy Precipitation Event along the Alpine South Side Using Potential Vorticity Inversion. Mon. Weather Rev. 2010, 138, 2336-2353. [CrossRef]

40. Pleșoianu, D.; Olariu, P. Câteva observații privind inundațiile produse în anul 2008 în bazinul Siretului. An. Univ. Ştefan Mare Suceava 2010, 19, 69-80.

41. Apostol, L.; Machidon, O. Impact of the abundant precipitations of 22-27 July 2008 in the north and north-east Moldova. Present Environ. Sustain. Dev. 2009, 3, 1-10.

42. WHO. Floods in Moldova, Romania, and Ukraine (Summer 2008). Available online: https://www.euro.who.int/en/healthtopics/health-emergencies/from-disaster-preparedness-and-response/policy/response/floods-2008 (accessed on 9 January 2021).

43. Zaxid Повені(Eng. Floods). Available online: https://zaxid.net/poveni_tag52230/newsfrom748/ (accessed on 9 January 2021).

44. Reliefweb Floods in Eastern Europe. (as of 29 Jul 2008). Available online: https://reliefweb.int/map/ukraine/floods-easterneurope-29-jul-2008 (accessed on 9 January 2021).

45. Boian, I.; Serenco, L.; Bejenaru, G.; Moldovanu, N. Evaluarea Inundaţiilor Catastrofale din Vara Anului 2010 pe Teritoriul Republicii Moldova. Available online: http:/ / old.meteo.md/mold/inundatii.htm (accessed on 18 January 2021).

46. Romanescu, G.; Constantin Stoleriu, C. Exceptional floods in the Prut basin, Romania, in the context of heavy rains in the summer of 2010. Nat. Hazards Earth Syst. Sci. 2017, 17, 381-396. [CrossRef]

47. Romanescu, G.; Mihu-Pintilie, A.; Stoleriu, C.C.; Carboni, D.; Paveluc, L.E.; Cimpianu, C.I. A comparative analysis of exceptional flood events in the context of heavy rains in the summer of 2010: Siret basin (NE Romania) case study. Water 2018, 10, 216. [CrossRef]

48. Șalaru, G.; Boian, I.; Serenco, L.; Bejenaru, G.; Moldovanu, N. Evaluarea inundaţiilor catastrofale din vara anului 2010 pe teritoriul Republicii Moldova. Mediu. Ambiant 2010, 5, 1-6.

49. Kundzewicz, Z.W.; Krysanova, V.; Dankers, R.; Hirabayashi, Y.; Kanae, S.; Hattermann, F.F.; Huang, S.; Milly, P.C.D.; Stoffel, M.; Driessen, P.P.J.; et al. Differences in flood hazard projections in Europe-Their causes and consequences for decision making. Hydrol. Sci. J. 2017, 62, 1-14. [CrossRef]

50. ICPDR. Floods in the Danube River Basin; Brief overview of key events and lessons learned; Vienna International Centre: Wagramer, Austria, 2012.

51. Epoch Times. România Bilanţ Cutremurător al Inundaţiilor din Botoşani. Available online: https://epochtimes-romania.com/ news / bilant-cutremurator-al-inundatiilor-din-botosani---84311 (accessed on 21 January 2021).

52. CARITAS. Situation Report: Floods in Romania-June 2010. Available online: https://reliefweb.int/sites/reliefweb.int/files/ resources/BAC3A79B57F282DBC12577520043C146-Full_Report.pdf (accessed on 21 January 2021).

53. DREF. Romania: Floods. Available online: https://reliefweb.int/sites/reliefweb.int/files/resources/887A8506CBD45074852577 5A006709DD-Full_Report.pdf (accessed on 21 January 2021).

54. EVZ. Bilanţul Inundaţiilor. Cod Roşu pe Prut. Available online: https://evz.ro/bilantul-inundatiilor-3-morti-sute-de-sinistrati2000-de-case-inundate-pe-prut-este-cod-ro.html/2 (accessed on 8 January 2021).

55. SHS. Raport Hidrologic Privind Viitura Pluvială din Luna Iunie 2020. Available online: http://www.meteo.md/images/uploads/ news/floods_2020/Raporthidrologicviiturile.pdf (accessed on 27 January 2021).

56. Ziare.com. Zece Comune din Judetul Galati Primesc Fonduri Speciale Pentru a Inlatura Efectele Inundatiilor si Alunecarilor de Teren. Available online: https:/ / ziare.com/galati/stiri-actualitate/zece-comune-din-judetul-galati-primesc-fonduri-specialepentru-a-inlatura-efectele-inundatiilor-si-alunecarilor-de-teren-8169641 (accessed on 28 January 2021).

57. CAPITAL. S-au dat Banii Pentru Localitătile Afectate de Inundatii. Available online: https://www.capital.ro/s-au-dat-baniipentru-localitatile-afectate-de-inundatii-353-de-milioane-de-lei-pentru-14-judete.html (accessed on 28 January 2021).

58. RFE/RL. Inundații în România: Viitura de pe Râul Prut a Ajuns la Intrarea în T,ară. Available online: https: / / romania.europalibera org/a/inundatii-in-romania-viitura-de-pe-raul-prut-a-ajuns-la-intrarea-in-tara/30689642.html (accessed on 28 January 2021).

59. DIGI24. Inundatii Devastatoare în Cea Mai Ploioasă Lună Iunie din Ultimii 60 de Ani. Available online: https: / / www.digi24.ro/stiri/actualitate/inundatii-devastatoare-in-cea-mai-ploioasa-luna-iunie-din-ultimii-60-de-ani-patruoameni-au-murit-o-fetita-a-fost-luata-de-viitura-1327761 (accessed on 28 January 2021).

60. HotNews. Bilanțul Inundațiilor: Trei Persoane Luate de Viitură, 71 Evacuate, Aproape 400 de Case Inundate. Available online: https: / / www.hotnews.ro/stiri-esential-24133784-inundatii-romania-bilant-igsu-trei-persoane-luate-viitura-71-evacuateaproape-400-case-inundate.htm (accessed on 28 January 2021). 
61. Ziaruldeiasi. Orban: Riscul cel Mai Mare îl Avem pe Prut, Unde Urmează să Intre în Ţară Viitura din Ucraina. Available online: https:/ / www.ziaruldeiasi.ro/stiri/ orban-riscul-cel-mai-mare-il-avem-pe-prut-unde-urmeaza-sa-intre-in-tara-viituradin-ucraina--256663.html (accessed on 28 January 2021).

62. NewsMarker. Digurile de Protecție de pe Râurile Prut și Nistru. Available online: https://newsmaker.md/ro/digurile-deprotectie-de-pe-raurile-prut-si-nistru-urmeaza-sa-fie-restabilite/ (accessed on 28 January 2021).

63. DSE. Indici Statistici Despre Numărul Situaţiilor Excepţionale ce s-au Produs în Republica Moldova pe Parcursul 1-30 June 2020. Available online: http:/ / dse.md/ro/date_statistice (accessed on 5 February 2021).

64. Promin. 3 НайбільшоїПовені на БуковиніПройшло12 Років, а Дамби й Досі Немає, Twelve years have passed since the Great Flood in Bukovyna, and the Dam is still missing. Available online: https://promin.cv.ua/2020/06/24/naibilshoi-poveni-nabukovyni-proishlo-12-rokiv-a-damby-i-dosi-nemaie.html (accessed on 1 February 2021).

65. Kundzewicz, Z.W.; Lugeri, N.; Dankers, R.; Hirabayashi, Y.; Döll, P.; Pińskwar, I.; Dysarz, T.; Hochrainer, S.; Matczak, P. Assessing river flood risk and adaptation in Europe-Review of projections for the future. Mitig. Adapt. Strateg. Glob. Chang. 2010, 15, 641-656. [CrossRef]

66. IPCC. Global Warming of $1.5^{\circ} \mathrm{C}$; An An IPCC Special Report on the impacts of global warming of $1.5^{\circ} \mathrm{C}$ above pre-industrial levels and related global greenhouse gas emission pathways, in the context of strengthening the global response to the threat of climate change; IPCC: Geneva, Switzerland, 2018.

67. World Bank. Romania Water Diagnostic Report: Moving toward EU Compliance, Inclusion, and Water Security; World Bank: Washington, DC, USA, 2018.

68. Apele Române. Planul Național de Management Actualizat Aferent Porțiunii din Bazinul Hidrografic International al Fluviului Dunăreacare este Cuprinsă în Teritoriul României 2016-2021; Administraţia Naţională Apele Române: Bucuresti, Romania, 2017.

69. Dniester Commission. Flooding in Western Ukraine: Causes, Lessons Learned and Potential to Avoid Harmful Future Effects. Available online: https:/ / dniester-commission.com/en/news/flooding-in-western-ukraine-causes-lessons-learned-andpotential-to-avoid-harmful-future-effects / (accessed on 16 February 2021).

70. MMSC Managementul. Riscului la Inundaţii. Available online: http://www.mmediu.ro/beta/domenii/managementul-apelor2/managementul-riscului-la-inundatii/ (accessed on 15 February 2021).

71. Maximyuk, O. Чому РічкиВиходять із Берегів на Буковині, а Калинівський Ринок неГотовий доПідтоплень, Why Rivers Leave the Shores in Bukovyna, and Kalynivsky Market Is Not Ready for Floods. Available online: https://shpalta.media/2020/0 6/24/chomu-richki-vixodyat-iz-beregiv-na-bukovini-a-kalinivskij-rinok-ne-gotovij-do-pidtoplen/ (accessed on 16 February 2021).

72. Hall, J.; Arheimer, B.; Borga, M.; Brázdil, R.; Claps, P.; Kiss, A.; Kjeldsen, T.R.; Kriaučuniene, J.; Kundzewicz, Z.W.; Lang, M.; et al. Understanding flood regime changes in Europe: A state-of-the-art assessment. Hydrol. Earth Syst. Sci. 2014, 18, $2735-2772$. [CrossRef]

73. Apel, H.; Thieken, A.H.; Merz, B.; Blöschl, G. Flood risk assessment and associated uncertainty. Nat. Haz. Earth Syst. Sci. 2004, 4, 295-308. [CrossRef]

74. Ralph, F.M.; Neiman, P.J.; Wick, G.A.; Gutman, S.I.; Dettinger, M.D.; Cayan, D.R.; White, A.B. Flooding on California's Russian River: Role of atmospheric rivers. Geophys. Res. Lett. 2006, 33, L13801. [CrossRef]

75. Rimbu, N.; Czymzik, M.; Ionita, M.; Lohmann, G.; Brauer, A. Atmospheric circulation patterns associated with the variability of River Ammer floods: Evidence from observed and proxy data. Clim. Past 2016, 12. [CrossRef]

76. Martius, O.; Zenklusen, E.; Schwierz, C.; Davies, H.C. Episodes of alpine heavy precipitation with an overlying elongated stratospheric intrusion: A climatology. Int. J. Climatol. 2006, 26, 1149-1164. [CrossRef]

77. Ionita, M.; Chelcea, S.; Rimbu, N.; Adler, M.-J. Spatial and temporal variability of winter streamflow over Romania and its relationship to large-scale atmospheric circulation. J. Hydrol. 2014, 519, 1339-1349. [CrossRef]

78. Hundecha, Y.; Merz, B. Exploring the relationship between changes in climate and floods using a model-based analysis. Water Resour. Res. 2012, 48. [CrossRef]

79. Steirou, E.; Gerlitz, L.; Apel, H.; Merz, B. Links between large-scale circulation patterns and streamflow in Central Europe: A review. J. Hydrol. 2017, 549, 484-500. [CrossRef]

80. Prudhomme, C.; Genevier, M. Can atmospheric circulation be linked to flooding in Europe? Hydrol. Process. 2011, 25, 1180-1190. [CrossRef]

81. Jacobeit, J.; Philipp, A.; Nonnenmacher, M. Atmospheric circulation dynamics linked with prominent discharge events in Central Europe. Hydrol. Sci. J. 2006, 51, 946-965. [CrossRef]

82. Mudelsee, M.; Börngen, M.; Tetzlaff, G.; Grünewald, U. Extreme floods in central Europe over the past 500 years: Role of cyclone pathway "Zugstrasse Vb". J. Geophys. Res. Atmos. 2004, 109. [CrossRef]

83. Froidevaux, P.; Martius, O. Exceptional integrated vapour transport toward orography: An important precursor to severe floods in Switzerland. Q. J. R. Meteorol. Soc. 2016, 142, 1997-2012. [CrossRef]

84. Payne, A.E.; Magnusdottir, G. Dynamics of landfalling atmospheric rivers over the North Pacific in 30 years of MERRA reanalysis. J. Clim. 2014, 27, 7133-7150. [CrossRef]

85. Hess, P.; Brezowsky, H. Katalog der Grosswetterlagen Europas; Deutscher Wetterdienst: Offenbach, Germany, 1952. 